\title{
A RESPONSABILIDADE TRIBUTÁRIA DAS SOCIEDADES INTEGRANTES DE GRUPOS ECONÔMICOS DE FATO: UMA ANÁLISE DOUTRINÁRIA E JURISPRUDENCIAL
}

Gustavo Telles da Silva*

\section{INTRODUÇÃO}

Os homens, como animais gregários que são, têm procurado, no decorrer da história, unir suas forças em sociedade a fim de desempenhar atividades que já não comportavam os esforços de um único indivíduo. As sociedades eram tidas como o meio pelo qual os indivíduos poderiam aglomerar seus potenciais, para pôr em prática resultados complexos que não poderiam ser obtidos através de um único homem. Com o passar do tempo e o desenvolvimento do capitalismo, algumas atividades passaram a ser tão complexas e desafiadoras que não eram mais desempenháveis somente por uma sociedade, surgindo a necessidade da união de duas ou mais para se alcançar resultados expressivos.

Os grupos de sociedade ou societários surgiram no período pós-guerra, de 1939 a 1945, como resultado das grandes mudanças na seara empresarial, causadas por profundas transformações sociais, e foram ganhando cada vez mais espaço em um contexto de crescimento dos grandes empreendimentos, sendo figuras presentes em diversos ramos das atividades econômicas ${ }^{1}$. Tais grupos podem significar grandes vantagens para as sociedades que os integram, através do "aumento da

\footnotetext{
* Agradeço os Professores da Universidade Federal Fluminense, Prof. Dra. Andressa Guimarães Torquato Fernandes e Prof. Dr. Marcus Wagner de Seixas, respectivamente orientadora e coorientador da presente monografia, pelos valiosos ensinamentos que contribuíram de maneira decisiva para o desenvolvimento deste trabalho.

1 LIMA, Marcelo Cordeiro de; MIRANDA, Bernadete. Grupo de empresas. Revista Virtual Direito Brasil, v. 3, n. 1, 2009.
} 
•• Tributação, direitos fundamentais e desenvolvimento

produtividade dos membros e da capacidade de comercializar e distribuir em grande quantidade seus produtos" ${ }^{2}$, ou seja, o aumento considerável dos lucros com uma significativa redução dos custos.

Porém, apesar dos grupos societários estarem cada vez mais presentes no dia a dia da sociedade brasileira e mundial, infelizmente o seu crescimento não foi acompanhado pela evolução legislativa do Brasil, que traz um disciplinamento esparso e bem vago sobre o tema.

O ordenamento jurídico brasileiro, com o advento da Lei n. 6.404/76 - Lei das Sociedades Anônimas, previu pela primeira vez os grupos societários de forma sistemática, adotando o modelo dualista alemão, que divide os grupos societários em grupos de direito e de fato. Os grupos de direito são constituídos através de um contrato celebrado entre as sociedades participantes, que deverá seguir todos os requisitos determinados pela Lei. Já os grupos de fato decorrem da interpretação do art. 243 e parágrafos da Lei das Sociedades Anônimas, que disciplina as formas de participação e de controle entre as sociedades ${ }^{3}$.

Apesar da legislação brasileira tratar dos grupos de direito com muito mais consistência do que o faz com os grupos de fato, a realidade empresarial do Brasil mostra que a maioria esmagadora dos grupos econômicos atuantes no país é de grupos de fato, que não se constituem através das formalidades estabelecidas pela Lei $\mathrm{n}$. 6.404/76. A partir disto, é possível identificar a tamanha fragilidade do regramento destinado aos grupos societários em nosso ordenamento, o que por vezes causa grandes problemas na prática, principalmente no tocante ao tema da responsabilidade.

A Lei n. 6.404/76, com o intuito de favorecer a constituição dos grupos societários e seguindo a vaguidade do ordenamento jurídico brasileiro sobre o tema, buscou trazer em seu bojo somente regras que catalisassem a constituição destes grupos, através de um anseio de fomento ao empreendedorismo, deixando de lado as regras que, por ventura, pudessem inibir este processo, o que explicaria a falta de dispositivos referentes à responsabilização.

Diante desta lacuna legislativa, diversos ramos do direito passaram a prever a responsabilização solidária ou subsidiária das sociedades agrupadas. Apesar da existência do arcabouço legislativo, que traz expressamente a questão da responsa-

TOMAZETTE, Marlon. Curso de direito empresarial: teoria geral e direito societário. 3. ed. São Paulo: Atlas, 2011. v. 1.

3 HOLLANDA, Pedro Ivan Vasconcelos. Os grupos societários como superação do modelo tradicional da sociedade comercial autônoma, independente e dotada de responsabilidade limitada. Dissertação (Mestrado), UFPR, Curitiba, 2008. 
A responsabilidade tributária das sociedades integrantes de grupos econômicos de fato • •

bilização das sociedades formadoras de um grupo societário no direito trabalhista, e consumerista, é possível perceber que não há norma geral destinada para este fim na seara tributária, figurando somente determinação expressa para o caso de créditos previdenciários.

Desta forma, a fim de analisar a responsabilidade tributária das sociedades integrantes de grupos societários de fato, o presente trabalho foi organizado em três capítulos. No primeiro, buscou-se realizar um estudo sobre o surgimento dos grupos societários e o seu disciplinamento pelo direito brasileiro. No segundo, abordou-se a conformação do fenômeno grupal com a teoria do direito societário clássico, imputado para as sociedades individualmente consideradas. Por fim, no terceiro capítulo, tratou-se da responsabilidade nos grupos societários, dos argumentos utilizados pelo fisco para justificar a responsabilização solidária das sociedades agrupadas e o tratamento dado ao tema pela jurisprudência do STJ.

\section{OS GRUPOS SOCIETÁRIOS}

\subsection{Aspectos históricos, formação e conceituação dos grupos econômicos}

Através de uma análise acerca das diferentes formaçôes societárias ao longo do tempo, percebe-se que a conjuntura política e econômica vigente produz forte influência no modelo de sociedade comercial adotado e, em consequência, também na estruturação própria do Direito Societário, tido como ramo interligado ao Direito Comercial.

Apesar de Santo estar com a razão ao dizer que os institutos societários-mercantis "são fenômenos multifacetados, aos quais não pode assinalar-se uma única gênese e uma evolução histórica linear"’4, didaticamente se observa a Idade Média como o berço histórico do Direito Societário, através da atuação dos comerciantes individuais. Estes sujeitos realizavam atividades preponderantemente artesanais e assumiam integralmente os riscos da atividade que desenvolviam, "não gozando de separação patrimonial e respondendo com todos os seus bens, inclusive os pessoais"

SANTO, João Espírito. Sociedades por quotas e anónimas - vinculação: Objecto social e representação plural. Coimbra: Almedina, 2000, p. 17.

5 RAMOS, André Luiz Santa Cruz. Direito empresarial esquematizado. 4. ed. rev., atual. e ampl. Rio de Janeiro: Forense; São Paulo, p. 45. 
•• Tributação, direitos fundamentais e desenvolvimento

Com o desenvolvimento da economia e das tecnologias e o crescente anseio do homem em descobrir novas terras, através das expediçôes Ultramarinas (século XVI e XVII), um modelo de multiplicidade de agentes econômicos individuais dispersos não se mostrava eficaz para suprir esta nova realidade. Através deste contexto, foram criadas as Companhias Coloniais, que eram capazes de manusear vultuosas quantias, necessárias à realização das expedições, e que trouxeram consigo a responsabilidade limitada e a livre circulação de açôes.

As Companhias Coloniais, constituídas e legalmente reconhecidas, trouxeram os primeiros balizamentos do que posteriormente, já em um contexto de Revolução Industrial, seriam as sociedades anônimas. Esta evolução, obviamente, não ocorreu de forma tão linear, pois as mudanças na expressão societária vinham como reação aos anseios políticos, econômicos e sociais da época. Porém, certo é que as Companhias Coloniais evoluíram naturalmente para a formação das sociedades anônimas. Para Tullio Ascarelli naquele momento

já se delineavam os característicos fundamentais, hoje peculiares da sociedade anônima e que a distinguem entre as várias espécies de sociedade: responsabilidade limitadas dos sócios e divisão do capital em ações, isto é, possibilidade de serem, as participaçôes dos vários sócios, corporificadas em títulos facilmente circuláveis; a pessoa do sócio é, destarte, indiferente à caracterização jurídica da sociedade ${ }^{6}$.

Com a Revolução Industrial (XVIII e XIX), era cada vez mais crescente a exigência pela concentração de capital, a fim de se investir na produção. Somente neste período histórico é possível observar a evolução da sociedade comercial, tendo em vista que, em nenhuma estrutura societária anterior se via conjugadas a autonomia, a independência e a responsabilidade limitada, características primordiais das sociedades anônimas. A partir da Revolução Industrial, a exploração da atividade econômica ganha cunho preponderantemente privado, não mais dependente de nenhuma autorização governamental para a criação das companhias? .

A sociedade Anônima, resultado evolutivo das sociedades comerciais através dos tempos, chegou a um patamar jurídico tal que, atualmente, configura-se como

ASCARELLI, Tullio. O desenvolvimento histórico do direito comercial e o significado da unificação do direito privado, p. 336, apud HOLLANDA, Pedro Ivan Vasconcelos. Os grupos societários como superação do modelo tradicional da sociedade comercial autônoma, independente e dotada de responsabilidade limitada. Universidade Federal do Paraná, Curitiba, 2008, p. 18. HOLLANDA, Pedro Ivan Vasconcelos. Os grupos societários como superação do modelo tradicional da sociedade comercial autônoma, independente e dotada de responsabilidade limitada. Universidade Federal do Paraná, Curitiba, 2008, p. 22. 
A responsabilidade tributária das sociedades integrantes de grupos econômicos de fato

importante mecanismo de concentração de capital, por ser ingrediente fundamental para a concentração empresarial. Hollanda muito bem sintetiza todo o desenvolvimento histórico já explicitado, ao dizer que

É com o grupo de sociedades que o direito empresarial inicia a terceira das fases históricas de seu desenvolvimento, sendo a primeira a do comerciante individual, dotado de um estatuto próprio, destacando-se do sujeito de direito comum; a segunda a da multiplicação das sociedades comerciais, com a vulgarização da sociedade anônima no século XIX como forma de instrumento de capitação do investimento popular; e a terceira o universo das multinacionais, das holdings, joint ventures e consórcios, formas de associações de empresas e representantes dos atuais personagens principais do cenário empresarial ${ }^{8}$.

A terceira fase do desenvolvimento do Direito Empresarial tem início no final do século XIX e início do século XX, com a chamada concentração empresarial, fenômeno onde um número cada vez menor de grandes empresas dominam os vários setores do mercado?. Esta concentração passou a ocorrer pelos mais diferentes motivos, sendo que todos acabam por encontrar uma razão existencial na Globalização e, consequentemente, no concentracionismo econômico.

A primeira fase desse movimento concentracionista abrangeu os fenômenos das concentrações primárias, entendidas como aquelas que ocorrem através de um crescimento interno das sociedades, mediante mecanismos empresariais como a fusão e a incorporação. Este tipo de operação empresarial logo começou a sofrer restrições por parte dos governos, tendo em vista o seu grande potencial monopolista. Além do que, provocava um crescimento exagerado das estruturas societárias, o que ocasionava graves problema de organização e de gestão ${ }^{10}$.

Diante disto, em meados do século XX, passou-se à segunda fase do movimento concentracionista, com as chamadas concentrações secundárias. Este fenômeno se dava, não mais pelo crescimento interno das sociedades, mas sim pelo crescimento externo, através da possibilidade de participação de uma sociedade em outra, criando-se "sujeitos jurídicos separados, sem prejuízo da unidade econômica”"11.

\section{Ibidem, p. 21.}

9 MARGONI, Anna Beatriz Alves. A desconsideração da personalidade jurídica nos grupos de sociedades. Dissertação apresentada à Faculdade de Direito da Universidade de São Paulo, São Paulo, 2011, p. 44.

10 PRADO, Viviane Muller. Conflito de interesses nos grupos societários. São Paulo: Quartier Latin, 2006, p. 18.

11 MARGONI, Anna Beatriz Alves. Op. cit., p. 48. 
-. Tributação, direitos fundamentais e desenvolvimento

Neste contexto, onde a concentração empresarial ocorre pela expansão externa da empresa, "mediante a aquisição do bloco de controle de outras sociedades"12, surgem os grupos societários, econômicos ou empresariais. Neste caso, segundo Prado

A sociedade inchada e isolada é substituída pela estrutura formada por um conjunto de sociedades que mantêm sua autonomia jurídica, patrimonial e organizacional, mas estão subordinadas a uma direção unificada. As sociedades individuais do início da Revolução Industrial deram lugar aos grupos de sociedades (...).

A conceituação dos grupos societários não se mostra matéria pacífica dentro da doutrina jurídica, nem mesmo a definição dos elementos que os caracterizam. Como bem salienta Claude Champaud, "os grupos são moléculas econômicas gigantes, cujas estruturas são tão diversas, tão originais, tão fecundas, tão complexas e tão dinâmicas que o jurista tem dificuldade para definir seus contornos"13.

Diante disto, José Engrácia Antunes entende que existam duas diferentes acepções da expressão "grupos de sociedades" sobre as quais seria possível se determinar um conceito. A primeira acepção seria a estrita, segundo a qual os grupos societários se distinguiriam pela independência jurídica das sociedades agrupadas, em relação à sociedade-mãe e pela dependência econômica daquelas em relação a esta. Assim, "todo o conjunto mais ou menos vasto de sociedades comerciais que, conservando embora as respectivas personalidades jurídicas próprias e distintas, se encontram subordinadas a uma direção econômica unitária e comum"14 , formariam um grupo societário.

Já a acepção ampla, corresponde ao "sector da realidade societária moderna que encontra no fenômeno do controlo intersocietário e das relações de coligação entre sociedades o seu centro de gravidade". Para Antunes seu objeto seria "o estudo e a disciplina da constituição, organização e funcionamento da sociedade enquanto entidade essencialmente dinâmica e "em relação", formando um "meta-direito das sociedades, um direito das sociedades de sociedades ou ainda um direito da sociedade de segundo grau"15. Do pensamento de Antunes, mais precisamente da acepção estrita, é possível destacar a principal característica dos grupos societários, que

PRADO, Viviane Muller. Op. cit., p. 18.

13 CHAMPAUD, Claude. Le pouvoir de concentration de la societé par actions, p. 302. Apud PINTO, Rodrigo Martins de Oliveira Silva. Os grupos de sociedades no direito antitruste: um estudo das concentrações empresariais. Curitiba, 2010.

14 ANTUNES, José A. Engrácia. Os grupos de sociedade estrutura e organização jurídica da empresa plurissocietária. 2. ed. Coimbra: Almedina, 2002, p. 52.

15 Ibidem, p. 53. 
A responsabilidade tributária das sociedades integrantes de grupos econômicos de fato

é a direção unitária. A doutrina, apesar de nutrir todo o tipo de controvérsia acerca do conceito de grupo societário, acaba por defender, de certa forma pacificamente, a direção unitária como elemento primordial do seu conceito.

Desta forma, diante dos mais variados conceitos encontrados na doutrina, é possível observar que, a maioria deles, acaba por conjugar duas características antagônicas, mas primordiais para a caracterização dos grupos, quais sejam, unidade e diversidade. A unidade está presente na organização econômica e subordinativa do grupo, pois as sociedades controladas ou dominadas estão subordinadas a uma unidade de estratégia e de direção econômica, definida pela sociedade controladora. Ao passo que a diversidade está ligada a autonomia jurídica, através da conservação das personalidades jurídicas de cada uma das sociedades que formam o grupo.

Alguns autores como Comparato e Salomão Filho, apesar de adotarem também a concepção estrita para definir os grupos societários ${ }^{16}$, acabam por defender que "os três elementos fundamentais de toda relação societária, a saber, a contribuição individual com esforços ou recursos, a atividade para lograr fins comuns e a participação em lucros ou prejuízos" ${ }^{17}$ estariam reunidos nos grupos societários e, por este motivo, eles constituiriam, em si mesmos, uma sociedade. Para os autores, apesar da legislação não reconhecer a personalidade jurídica do grupo, a unidade de direção implicaria em uma necessária confusão patrimonial entre as sociedades agrupadas, que formariam uma chamada "sociedade de $2^{\circ}$ grau" 18 .

Outro importante autor que comunga deste mesmo entendimento é Jorge Lobo, defensor da personificação dos grupos societários como forma de garantir a satisfação de obrigações junto a credores externos das sociedades agrupadas. Para ele,

O grupo está para as sociedades grupadas assim como a sociedade isolada está para a pessoa de seus sócios ou acionistas: nesta, como naquele, a pessoa dos membros não se confunde com a instituição resultante da união das diversas partes (...) uma e outra, tal como seus componentes, possuem personalidade ${ }^{19}$.

16 "A melhor doutrina considera a unidade de direção o único critério geral de identificação de todos os grupos econômicos" (COMPARATO e SALOMÃO FILHO, 2008, p. 43).

17 COMPARATO, Fábio Konder; SALOMÃO FILHO, Calixto. O poder de controle na sociedade anônima. 5. ed. Rio de Janeiro. Forense. 2008, p. 43.

18 Ibidem, p. 360.

19 LOBO, Jorge. Direito dos grupos de sociedades. Revista de Direito Mercantil, Industrial, Econômico e Financeiro, São Paulo, RT, n. 107, p. 99-122. Apud PINTO, Rodrigo Martins de Oliveira Silva. Os grupos de sociedades no direito antitruste: um estudo das concentraçôes empresariais. Curitiba, 2010. 
•• Tributação, direitos fundamentais e desenvolvimento

Para a discussão sobre a solidariedade tributária das empresas que integram um grupo econômico, é mister aprofundar o debate sobre o tema da personificação dos grupos como sociedades de $2^{\circ}$ grau, o que será feito em momento posterior neste trabalho. Porém, para isto é fundamental que, antes, realize-se uma análise sobre o regramento adotado pela legislação societária brasileira no que tange os grupos societários.

\subsection{Disciplina da Lei n. $6.404 / 76$ sobre os Grupos Societários: os Grupos de Direito e de Fato}

A Lei n. 6.404 de 1976, chamada de Lei das Sociedades Anônimas, foi o diploma normativo que inaugurou o regramento sobre os grupos societários no ordenamento jurídico brasileiro. O Brasil foi o segundo país, no mundo, a adotar uma legislação que tratasse de tais grupos, tendo sido a Alemanha o primeiro a fazê-lo ${ }^{20}$.

A Lei das Sociedades Anônimas foi resultado do Segundo Plano Nacional de Desenvolvimento (II PND), formulado no governo Geisel, que tinha como principais escopos "o fortalecimento da empresa privada nacional e a formação de conglomerados econômicos brasileiros para fazer frente às empresas estrangeiras"21, dentro de um contexto onde o governo buscava traçar metas para o desenvolvimento econômico do país.

O regramento trazido por esta Lei sobre os grupos societários é bastante simplificado, o que ocasionou, na prática do direito empresarial, diversos problemas concretos, como é o caso da questão trazida à baila neste trabalho. Esta característica, porém, não era algo obscuro, mas, pelo contrário, vinha justificada na própria exposição de motivos escrita por Mário Henrique Simonsen, então Ministro da Fazenda

5. (...) os institutos novos para a prática brasileira - grupamento de sociedades, oferta pública de aquisição de controle, cisão de companhias e outros - estão disciplinados de forma mais simplificada para facilitar sua adoção, e no pressuposto de que venham a ser corrigidos se a prática indicar essa conveniência.

O Direito brasileiro, ao disciplinar os grupos societários, inspirou-se no modelo dualista alemão, abrangendo os grupos constituídos mediante convenção grupal, chamados grupos de direito e os grupos que decorrem do exercício do poder

\footnotetext{
20 PRADO, Viviane Muller. Conflitos de interesses nos grupos societários. São Paulo: Quartier Latin, 2006, p. 48.

21 Ibidem, p. 48.
} 
A responsabilidade tributária das sociedades integrantes de grupos econômicos de fato

de controle pela controladora nas sociedades controladas, que a doutrina acabou por chamar de grupos de fato. Isto fica evidenciado pela Exposição de Motivos da Lei n. 6.404/76, ao dizer que:

(...) o Projeto distingue duas espécies de relacionamento entre sociedades, quais sejam: a) sociedades coligadas, controladoras e controladas, que mantem entre si relações societárias segundo regime legal de sociedades isoladas e não se organizam em conjunto, reguladas neste capítulo; b) sociedades controladoras e controladas que, por convenção levada ao Registro do Comércio, passam a constituir grupo societário, com disciplina própria, prevista no Capítulo XXI.

No sistema dual, a diferenciação central para a determinação de cada grupo societário se dá na observação da natureza do vínculo existente entre as sociedades. É preciso estar atento para verificar se a ligação entre as sociedades ocorre através de uma convenção grupal ou decorre da mera participação de uma sociedade no capital social da outra, a ponte de lhe conferir o poder de controle.

\subsubsection{Grupos Societários de Direito}

Os grupos de direito estão disciplinados no Capítulo XXI da Lei n. 6.404/76, que abrange os preceitos positivados nos arts. 265 ao 277. Estes grupos são formados, necessariamente, através de um instrumento formal, ficando sujeitos à aplicação de um regime jurídico específico, diferenciado em relação aos ditames do direito das sociedades. O legislador definiu esta espécie de grupamento no art. 265 e parágrafos da Lei do anonimato, in verbis:

Art. 265. A sociedade controladora e suas controladas podem constituir, nos termos deste Capítulo, grupo de sociedades, mediante convenção pela qual se obriguem a combinar recursos ou esforços para a realização dos respectivos objetos, ou a participar de atividades ou empreendimentos comuns.

$\$ 1^{\circ}$ A sociedade controladora, ou de comando do grupo, deve ser brasileira, e exercer, direta ou indiretamente, e de modo permanente, o controle das sociedades filiadas, como titular de direitos de sócio ou acionista, ou mediante acordo com outros sócios ou acionistas.

$\$ 2^{\circ}$ A participação recíproca das sociedades do grupo obedecerá ao disposto no artigo 244 .

O grupo de direito será constituído por convenção aprovada por todas as sociedades que o componham, que deverá conter em seu bojo, dentre outros requisitos,

(I) a indicação da sociedade de comando e as filiadas; (II) as condições de participação das diversas sociedades e (III) os órgãos e cargos da administração do 
•• Tributação, direitos fundamentais e desenvolvimento

grupo, suas atribuições e as relações entre a estrutura administrativa do grupo e as sociedades que o componham (art. 269).

As sociedades filiadas deverão observar as orientaçôes gerais determinadas pela administração do grupo, podendo haver a subordinação dos interesses de uma das sociedades aos de outra ou aos interesses do próprio grupo (art. 276). Segundo Prado, no contrato de formação do grupo

há a negociação do poder de direção interna das sociedades e a distribuição de competência de uma sociedade para os órgãos do grupo. Origina uma nova organização, passando a controladora a ter o direito de estabelecer as diretrizes sobre a condução dos negócios das filiadas. Nesta organização, o interesse do grupo, isto é, o interesse da própria organização plurissocietária tem relevância e recebe a proteção do direito. Constata-se, assim, que a convenção de formação do grupo caracteriza o rompimento nas estruturas das sociedades isoladas, pois as suas características são estranhas aos pressupostos societários de autonomia e independência ${ }^{22}$.

Porém, mesmo existindo uma unidade administrativa nos grupos de direito e possuindo eles interesses específicos, o grupo não constitui uma pessoa jurídica, persistindo a personalidade jurídica e patrimônios de cada sociedade agrupada.

Atrelando as principais determinações contidas nos artigos da lei referentes aos grupos de direito e corroborando o que já foi dito, Antunes conceitua tais grupos como sendo

aqueles cuja criação resulta da utilização de um dos instrumentos jurídicos que a lei previu taxativamente para tal efeito (...), e a cuja organização e funcionamento se fez associar um regime jurídico excepcional, derrogador dos cânones gerais do direito das sociedades - regime esse traduzido, por um lado, na legitimação do exercício de um poder de direcção da sociedade mãe sobre as sociedades-filhas e da subordinação dos interesses sociais individuais destas ao interesse geral do grupo (em derrogação do princípio fundamental segundo o qual a sociedade deve conduzir os negócios sociais à luz da sua vontade e interesse social próprios) e, por outro, no estabelecimento de contrapartidas especiais de proteção para estas últimas sociedades, seus sócios minoritários e credores sociais ${ }^{23}$.

A Lei das Sociedades Anônimas, ao disciplinar os grupos de direito, adotou o critério contratual, onde somente através de um instrumento formal seria possível legitimar a unidade econômica de todas as sociedades filiadas. Os grupos de

22 PRADO, Viviane Muller. Grupos societários: análise do modelo da Lei 6.404/1976. Revista Direito GV, São Paulo, v. 1, n. 2, p. 5-28, jun./dez. 2005, p. 11.

23 ANTUNES, José A. Engrácia. Os grupos de sociedade estrutura e organização jurídica da empresa plurissocietária. 2. ed. Coimbra: Almedina, 2002, p. 73. 
A responsabilidade tributária das sociedades integrantes de grupos econômicos de fato

direito então, seriam os únicos verdadeiramente reconhecidos pelo legislador, pois apenas a eles se aplica o regime jurídico específico disposto na Lei em questão.

Segundo Prado, a lógica do modelo dual reside no fato de que "os grupos empresariais com intenção de funcionar como unidade econômica iriam se valer (e a princípio teriam esse interesse) dos instrumentos próprios à formação dos grupos de direito" 24 , tendo em vista que "o contrato legaliza a relação de dependência" 25 . Assim, segundo a autora, "os grupos de fato seriam uma exceção"26.

Porém, a realidade do cenário empresarial brasileiro é completamente diferente desta previsão, tendo em vista ser rara a utilização da convenção prevista nos arts. 265 e seguintes da Lei n. 6.404/76.

Fábio Konder Comparato, ao apreciar o anteprojeto da Lei do anonimato em 1975, já tecia comentários pessimistas sobre o modelo dual que se pretendia positivar no ordenamento jurídico brasileiro ${ }^{27}$. Após a entrada em vigor da referida Lei acabou por se confirmar sua previsão, fato destacado por Calixto Salomão Filho em sua obra de 1998, ao asseverar que

Não é exagerado dizer que o direito grupal brasileiro enfrenta momento de séria crise. Do modelo original praticamente nada resta. As principais regras conformadoras do direito grupal como originalmente idealizado encontram-se hoje sepultadas pela prática ou pelo legislador. Os grupos de direito no Brasil são letra absolutamente morta na realidade empresarial brasileira ${ }^{28}$.

Diante disto, a realidade empresarial do país vive um cenário conturbado, tendo em vista que a maioria esmagadora das formações grupais são realizadas de acordo com o frágil regramento oferecido pela Lei n. 6.404/76, no que tange ao exercício do poder de controle nas coligadas, controladoras e controladas, denominado grupos de fato, como se verá no próximo tópico.

24 PRADO, Viviane Muller. Conflitos de interesses nos grupos societários. São Paulo: Quartier Latin, 2006, p. 69.

25 Ibidem, p. 69.

26 Ibidem, p. 69.

27 COMPARATO, Fábio Konder. Anteprojeto de lei de sociedades por açōes. Revista de Direito Mercantil 17/122, 1975. Apud PRADO, Viviane Muller. Grupos societários: análise do modelo da Lei 6.404/1976. Revista DireitoGV, v. 1, n. 2, p. 5-28, jun./dez. 2005, p. 6.

28 SALOMÃO FILHO, Calixto. O novo direito dos grupos: conflito de interesses "versus" regra de responsabilidade. O novo direito societário. São Paulo: Malheiros, 1998, p. 169. Apud PRADO, Viviane Muller. Grupos societários: análise do modelo da Lei 6.404/1976. Revista DireitoGV, v. 1, n. 2, p. 5-28, jun./dez. 2005, p. 6. 
•• Tributação, direitos fundamentais e desenvolvimento

\subsubsection{Grupos societários de fato}

A Lei n. 6.404/76, como já dito anteriormente, adotou o modelo dual, determinando um regramento específico para os grupos societários de direito, também chamados de grupos contratuais. Em relação aos grupos de fato a Lei em questão não disciplinou, propriamente, regramentos específicos, mas sim trouxe determinações sobre o exercício do poder de controle por uma sociedade sobre outra, que acabou por ser interpretado pela doutrina brasileira como o reconhecimento, pelo legislador, do fenômeno dos grupos de fato.

Esta interpretação doutrinária tem como objeto o art. 243 da Lei das Sociedades Anônimas, que traz as balizas do poder de controle para a configuração das sociedades coligadas, controladas e controladoras. Em seu $₫ 2^{\circ}$ o dispositivo em questão determina que são controladas as sociedades na qual a controladora, diretamente ou indiretamente participa do capita social, de modo que lhe assegure, permanentemente, preponderância nas deliberações sociais e o poder de eleger a maioria dos administradores, in verbis:

Art. 243. O relatório anual da administração deve relacionar os investimentos da companhia em sociedades coligadas e controladas e mencionar as modificaçōes ocorridas durante o exercício.

$\$ 1^{\text {o }}$ São coligadas as sociedades nas quais a investidora tenha influência significativa.

$\$ 2^{\circ}$ Considera-se controlada a sociedade na qual a controladora, diretamente ou através de outras controladas, é titular de direitos de sócio que lhe assegurem, de modo permanente, preponderância nas deliberaçôes sociais e o poder de eleger a maioria dos administradores.

$\$ 3^{\circ}$ A companhia aberta divulgará as informações adicionais, sobre coligadas e controladas, que forem exigidas pela Comissão de Valores Mobiliários.

$\$ 4^{\circ}$ Considera-se que há influência significativa quando a investidora detém ou exerce o poder de participar nas decisões das políticas financeira ou operacional da investida, sem controlá-la. (Incluído pela Lei n. 11.941, de 2009)

$\$ 5^{\circ}$ É presumida influência significativa quando a investidora for titular de $20 \%$ (vinte por cento) ou mais do capital votante da investida, sem controlá-la.

Além disto, o citado artigo também trata de outra relação entre sociedades, a coligação. $\mathrm{O}$ legislador define as sociedades coligadas como sendo aquelas nas quais a investidora possua influência significativa, ou seja, detenha ou exerça o poder de participar nas decisões das políticas financeiras ou operacionais, sem controlá-la. Determina ainda que a influência significativa é presumida quando a investidora for titular de $20 \%$ ou mais do capital volante da investida, sem controlá-la. 
A responsabilidade tributária das sociedades integrantes de grupos econômicos de fato

O Código Civil de 2002 também previu em seu texto disciplina sobre as sociedades coligadas, controladas e controladoras, mais precisamente em seus arts. 1.097 ao 1.101. Porém, restringiu-se somente em descrever as situações de ligação entre sociedades, não especificando regramentos próprios para a participação de sociedade no capital de outra. Leães, ainda na fase do Anteprojeto do Código Civil, destacou que "o que mais se lamenta nesse capítulo é a inexistência de qualquer medida de proteção à minoria acionária e aos credores sociais. Sem tais armas, o capítulo das definições restou ineficaz" ${ }^{29}$.

Os grupos societários de fato, na visão da Lei n. 6.404/76, são, então, a relação entre sociedade controladora e sociedades controladas, onde a controladora exerce um poder de fato e não legal, razão pela qual recebeu a denominação grupo de fato. Diante disto, percebe-se que o critério adotado para a verificação destes grupos é o poder de controle, "sem existir qualquer outro elemento ulterior que demonstre a unidade econômica do grupo, ressalvados os grupos de direito"30. Outra característica arterial do direito brasileiro é que a Lei n. 6.404/76 somente permite a direção unitária quando existir convenção grupal, de onde se extrai a importante indagação feita por Viviane Muller Prado: “é possível reconhecer os grupos de sociedades de fato com unidade econômica no direito brasileiro?31".

A autora então esclarece a questão dizendo que, inicialmente, a resposta seria negativa, considerando-se que a sociedade, ao exercer seu poder de controle deve se ater exclusivamente ao seu interesse social. Porém, deixa claro que esta resposta está pautada somente no aspecto formal da sociedade isoladamente considerada e no fato da legislação apenas fazer referência expressa ao controle. Além do que, para responder à questão negativamente, seria necessário ignorar totalmente a realidade da organização grupal no Brasil ${ }^{32}$.

Isto posto, a fim de dar uma resposta positiva para a indagação, Prado esclarece que é necessário analisar a estrutura do poder de controle, ensinando que quando uma sociedade participa do capital de outras sociedades, direta ou indiretamente, ela tem duas opções:

29 LEÃES, Luiz Gastão Paes de Barros. Sociedades coligadas e consórcio, p. 143 Apud PRADO, Viviane Muller. Conflitos de interesses nos grupos societários. São Paulo: Quartier Latin, 2006, p. 140.

30 PRADO, Viviane Muller. Conflitos de interesses nos grupos societários. São Paulo: Quartier Latin, 2006, p. 141.

31 Ibidem, p. 155.

32 Ibidem, p. 155. 
-. Tributação, direitos fundamentais e desenvolvimento

A primeira é exercer o poder de controle em todas as sociedades controladas e influenciar nas respectivas administrações, seguindo uma estratégia unificada para o conjunto de sociedades. A segunda opção é exercer o poder de controle em cada uma delas de forma isolada, sem pretender a unidade e coordenação. Na primeira hipótese, afirma-se que há uma relação de grupo, enquanto na segunda há apenas a relação de controle. (...) Nos grupos, o controlador não tem apenas o interesse de obter os direitos relacionados com a sua posição de sócio, mas também os exerceria de forma a coordenar as atividades de todas as empresas para atingir o melhor resultado global ${ }^{33}$.

O grupo societário de fato, então, estará configurado quando o controlador extrapolar os seus interesses, buscando benefícios que vão além daqueles obtidos como sócio, adotando uma forma especial de exercer o poder de controle. Assim, "o controlador passa a exercer, profissionalmente e com métodos próprios, a atividade de coordenação e administração de todas as sociedades conjuntamente" 34 .

Quando a sociedade que detém o controle escolhe pela organização na forma de grupo de fato não está ela cometendo qualquer ilícito. Porém, o ponto crucial da discussão encontra refúgio na organização interna das sociedades controladas, "pois no grupo de fato, não pode a sociedade controladora impor diretrizes às demais, como nos grupos convencionais" 35 .

A Lei n. 6.404/76 somente previu um arcabouço disciplinador para os grupos societários de direito, o que impôs a necessidade dos grupos societários de fato serem regidos pelas regras do direito societário, que é construído a partir de uma visão da sociedade isolada. Isto pode ser observado no disciplinamento dado pelos art. 245, 246 e 117 da Lei n. 6.404/76, in verbis:

Art. 245. Os administradores não podem, em prejuízo da companhia, favorecer sociedade coligada, controladora ou controlada, cumprindo-lhes zelar para que as operaçôes entre as sociedades, se houver, observem condições estritamente comutativas, ou com pagamento compensatório adequado; e respondem perante a companhia pelas perdas e danos resultantes de atos praticados com infração ao disposto neste artigo.

Art. 246. A sociedade controladora será obrigada a reparar os danos que causar à companhia por atos praticados com infração ao disposto nos artigos 116 e 117.

Art. 117. O acionista controlador responde pelos danos causados por atos praticados com abuso de poder.

\footnotetext{
Ibidem, p. 155-156.

Ibidem, p. 157.

35 Ibidem, p. 158.
} 
A responsabilidade tributária das sociedades integrantes de grupos econômicos de fato

Já na Exposição de Motivos da Lei n. 6.404/76 era possível perceber a incoerência que se estava por construir no direito societário brasileiro, através da contraposição da unidade econômica e da diversidade jurídica dos grupos societários de fato. Por um lado, o texto justificativo reconhecia como "nova realidade" a expansão da grande empresa através da criação de "constelações de sociedades coligadas, controladoras e controladas". Por outro, determinava que sociedades coligadas, controladoras e controladas deveriam "manter entre si relaçôes societárias segundo o regime legal de sociedades isoladas, não se organizando em conjunto" conforme regulado pela Lei.

Esta situação impõe aos grupos societários de fato uma barreira dificilmente respeitada, que é o exercício do poder de controle sem que haja conflito de interesse ou abuso de poder, ou seja, o controlador deve exercer seu poder para dar unidade econômica às várias sociedades, levando em conta o interesse de cada uma delas, impedindo-se que aufira vantagens para si ou para outra sociedade em detrimento das controladas ${ }^{36}$.

\subsection{A Estrutura das Empresas Brasileiras e o modelo da Lei n. 6.404/76}

A Lei n. 6.404/76, baseada em razões econômicas de dar liberdade ao empresário para a formação de conglomerados, importou o Sistema Dualista Germânico, que trazia uma disciplina abrangente sobre os grupos de direito e algumas regras específica dos grupos de fato. Segundo a lógica do modelo importado, somente a convenção grupal poderia legalizar a relação de dependência econômica das sociedades agrupadas, entendimento segundo o qual "o grupo de fato seria uma exceção, servindo às estruturas descentralizadas, com grande autonomia das controladas" 37 .

Porém, o que se observa na realidade empresarial brasileira é bastante diverso da racionalidade da Lei. Fábio Konder Comparato, 20 anos após a publicação da Lei n. $6.404 / 76$, informou que se tinha conhecimento do registro de somente 30 grupos de direito no Departamento Nacional de Registros de Empresa até aquele momento ${ }^{38}$.

36 PRADO, Viviane Muller. Conflitos de interesses nos grupos societários. São Paulo: Quartier Latin, 2006, p. 158.

37 PRADO, Viviane Muller. Grupos societários: análise do modelo da Lei 6.404/1976. Revista Direito GV, São Paulo, v. 1, n. 2, jun./dez. 2005, p. 13.

38 Op. cit., p. 158 apud Informação retirada de texto distribuído pelo Prof. Fábio Konder Comparato na pós-graduação da Faculdade de Direito da USP, na disciplina ministrada no segundo semestre de 1996, denominada Grupos de Empresas em Direito Comercial Comparado. 
-. Tributação, direitos fundamentais e desenvolvimento

A falência do modelo dual no ordenamento jurídico brasileiro não importa significar que não existam grupos societários no Brasil. Pelo contrário, as grandes empresas brasileiras somente não utilizam o instrumento para a formação do grupo, organizando-o a partir do poder de controle societário, ou seja, através da formação de grupos de fato. Tal é esta constatação, que as 200 maiores empresas que atuam no Brasil se organizam por meio de estruturas complexas plurissocietárias ${ }^{39}$.

Muitas são as razões para a não adoção dos grupos convencionais no Brasil, sendo possível destacar, segundo Prado:

A artificialidade do modelo importado, a facultatividade de formação de grupos convencionais e a oneração com o direito de recesso dos minoritários e com a estrutura administrativa (...) deve ser levada em conta a insegurança na interpretação do regime jurídico dos grupos de direito na legislação brasileira ${ }^{40}$.

A facultatividade está relacionada com a não imposição, pela lei, da adoção do contrato e do regime jurídico específico para a formação do grupo, dependendo somente da manifestação de vontade dos interessados na sua formação pela adoção ou não da figura contratual.

A artificialidade, por sua vez, está atrelada com a importação parcial de um modelo disciplinador dos grupos societários que não possuía qualquer tradição no Brasil. Os altos custos estão relacionados, principalmente, com a previsão do direito de retirada previsto nos arts. 137 c/c 136, V e 270, parágrafo único da Lei. 6.404/76, segundo os quais os sócios ou acionistas minoritários que não concordarem com a participação em grupo de sociedades têm o direito de se retirarem da sociedade, mediante o recebimento dos valores referentes às suas ações ou cotas. Segundo Prado, estas despesas surgem somente quando se escolhe pelo grupo de direito, pois:

a legitimação da unidade do grupo não é suficiente para o empresário incorrer em tais despesas. A participação majoritária no capital da sociedade, sem base contratual, também proporciona o poder de controle sobre a empresa, sem o ônus de pagar aos minoritários o recesso, obviamente o empresário opta por não adotar a estrutura do grupo convencional ${ }^{41}$.

Por fim, deve-se atentar para a questão da insegurança interpretativa do regime jurídico destinado a disciplinar os grupos societários no direito brasileiro. Isto

Valor Grandes Grupos, n. 3, dez. 2004.

40 PRADO, Viviane Muller. Grupos societários: análise do modelo da Lei 6.404/1976. Revista Direito GV, São Paulo, v. 1, n. 2, jun./dez. 2005, p. 15.

41 Ibidem, p. 15-16. 
A responsabilidade tributária das sociedades integrantes de grupos econômicos de fato

porque o ordenamento jurídico pátrio está anos luz atrás do desenvolvimento do instituto na realidade empresarial brasileira. Nem mesmo os tribunais encontram harmonia ao tratar da questão.

Há na realidade empresarial modelos organizacionais que não partem de preceitos legais, mas que levam em conta “as demandas estratégicas das empresas e as peculiaridades de cada mercado, inexistindo um modelo único para estruturar a organização da empresa"’2. Esta necessária flexibilização esbarra na rigidez do modelo dual, o que privilegia os grupos de fato. Segundo Prado:

Nos grupos de fato é que se encontra o local para a organização do poder empresarial. Sob o aspecto do direito, a independência jurídica representa a existência de centros autônomos produtivos, com organização interna própria, mesmo que pertençam a um grupo maior de interesses. Por outro lado, a posição de sócio ou acionista controlador dá ao seu titular o poder de tomar as decisôes mais importantes sobre a condução dos negócios sociais. Uma das razões para a formação dos grupos é justamente esta flexibilidade da estrutura empresarial ${ }^{43}$.

\section{PARADOXO ENTRE OS GRUPOS SOCIETÁRIOS E O DIREITO SOCIETÁRIO TRADICIONAL}

O presente trabalho, até este momento, procurou demonstrar como se deu o surgimento dos grupos societários na realidade jurídica mundial e como o ordenamento jurídico brasileiro internalizou o instituto. De todo o exposto, é possível destacar que o modelo adotado pelo direito brasileiro é parcial, na medida em que oferece um disciplinamento específico somente para os grupos de direito, devendo os grupos de fato obedecerem a disciplina aplicável às sociedades isoladas e, também, que a realidade empresarial brasileira adotou esmagadoramente os grupos de fato, em detrimento dos grupos de direito.

Da conjugação destas constatações se retira uma assustadora conclusão, qual seja, "as sociedades que formam um grupo de fato submetem-se a um regime jurídico que as trata como se fossem economicamente autônomas" ${ }^{34}$. No direito alemão, de onde o direito brasileiro buscou inspiração, a questão não é encarada da mesma maneira. Isto porque, a jurisprudência do país criou a figura do grupo de

\footnotetext{
Ibidem, p. 17.

Ibidem, p. 17.

44 PRADO, Viviane Muller. Grupos societários: análise do modelo da Lei 6.404/1976. Revista

Direito GV, São Paulo, v. 1, n. 2, jun./dez. 2005, p. 18.
} 
•• Tributação, direitos fundamentais e desenvolvimento

fato qualificado ${ }^{45}$, reconhecendo-se a direção unificada, mesmo não existindo contrato, o que faz com que seja aplicada a eles as regras sobre grupos de direito no que tange à proteção dos credores e dos sócios minoritários ${ }^{46}$.

Por sua vez, os dogmas do direito societário sobre os quais se construiu o regime jurídico aplicado às sociedades isoladamente, quais sejam, a autonomia de controle, a independência jurídica e a responsabilidade limitada não se coadunam com os grupos societários, pois idealizados para "uma sociedade comercial dotada de autonomia e isenta da influência de uma entidade societária externa, que responda apenas pela prática de seus próprios atos e cuja personalidade jurídica não era colocada em xeque (...)" ${ }^{3 / 7}$.

Nos grupos societários, ao contrário, o que se vê é a dependência da sociedade controlada aos ditames estabelecidos pela sociedade controladora, a responsabilização comum das sociedades do grupo, em alguns casos previstos em lei e uma flexibilização da personalidade jurídica das sociedades agrupadas.

Deste conflito, resulta um abismo que se aloca entre o fenômeno grupal, principalmente no tocante aos grupos de fato, pois não possuem regramento próprio, e os preceitos do direito societário, o que provoca uma enorme e indesejada insegurança jurídica, seja para aqueles que se organizam em forma de grupo, seja para seus credores e sócios minoritários.

\subsection{A autonomia de controle e os grupos societários}

Segundo o direito societário tradicional, a autonomia da sociedade compreende "a liberdade de seu comando de acordo com a vontade, interesses e objetivos estabelecidos pela própria sociedade, sem que se faça presente a influência, interna ou externa de uma outra sociedade”48. A sociedade anônima é uma pessoa jurídica e, como tal, é tratada pelas regras e princípios do direito societário como um sujeito de direito autônomo. Prado observa que tais regras e princípios:

objetivam a regulamentação de um ente hermético, pressupondo a inexistência de influências externas no desenvolvimento das suas atividades. A disciplina legal diz respeito à formação, captação de recursos, organização, administração, fiscalização e

Qualifizierter faktischer konzern.

6 PRADO, Viviane Muller, op. cit., p. 18.

47 HOLLANDA, Pedro Ivan Vasconcelos, op. cit., p. 104.

48 Ibidem, p. 106. 
A responsabilidade tributária das sociedades integrantes de grupos econômicos de fato

dissolução da sociedade isolada. (...) A independência legal da sociedade é baseada na presunção da sua independência econômica que, por sua vez, expressa-se no conceito de interesse social ${ }^{49}$.

O fenômeno grupal, como já dito anteriormente, representa uma unidade econômica em uma diversidade jurídica, realidade que rompe drasticamente com esta noção tradicional de autonomia, na medida em que estão presentes em sua formação diferentes interesses. Esta nova realidade do campo jurídico-societário desloca o estudo do interesse social de uma análise da sociedade isoladamente considerada, para o fenômeno grupal. Neste sentido, Antunes enfatiza que:

(...) a doutrina nacional e estrangeira não mais deixou de sublinhar a confluência no seio da sociedade de uma multiplicidade de interesses individuais distintos e até antagónicos (...). Numa linha paralela de considerações, é também hoje cada vez mais evidente que o interesse social não pode ser concebido de um modo puramente atomístico e asséptico - como uma espécie de interesse ideal auto-referencialmente hipostasiado de uma entidade empresarial abstractamente autónoma -, constituindo antes um interesse que pode ser permeável às determinantes concretas provenientes da sua própria envolvente económico-empresarial, maxime, aos interesses de outras empresas societárias que com ela possuam estreitas relaçōes de interdependência ou agrupamento ${ }^{50}$.

A Lei n. 6.404/76, no que tange ao tema da autonomia societária, permite a subordinação dos interesses de uma sociedade aos de outra ou aos do grupo (art. 276). Porém, esta permissão somente é direcionada aos grupos convencionais, não se estendendo aos grupos de fato. Nestes, o interesse da sociedade isolada deve ser observado, sob pena de se configurar abuso do poder de controle e conflito de interesse (arts. 246 e 115). A partir deste entendimento é possível observar uma enorme contradição entre o sistema legal e a realidade empresarial, pois, apesar do direito societário tutelar um ente isolado e independente, constata-se na realidade empresarial um "círculo de dependência e subordinação" ${ }^{1}$ como ocorre perante os grupos de fato. Para Antunes:

o sistema normativo do moderno Direito das Sociedades Comerciais tem em si ínsito um verdadeiro paradoxo, repousando in toto numa congênita, quase esquizofrênica, contradição interna: a regulação jurídica da sociedade comercial encontra-se adjudicada

49 PRADO, Viviane Muller. Conflitos de interesses nos grupos societários. São Paulo: Quartier Latin, 2006, p. 66.

50 ANTUNES, José Augusto Quelhas Lima Engrácia. Os grupos de sociedades: estrutura e organização jurídica da empresa plurisocietária. 2. ed., rev. e atual. Coimbra: Almedina, 2002, p. 107.

51 HOLLANDA, Pedro Ivan Vasconcelos, op. cit., p. 111. 
a um ramo de direito que se encontra assente em princípios regulatórios conflituantes entre si (a sociedade como entidade independente e soberana 'versus' a sociedade como entidade dependente e controlada) e que promove modelos regulatórios de organização empresarial igualmente concorrentes ou opostos (a empresa unissocietária versus a empresa plurissocietária) ${ }^{52}$.

$\mathrm{Na}$ legislação brasileira existem diversos dispositivos que, de forma veemente, preveem e defendem a autonomia da sociedade comercial, como pode ser visto pela leitura dos artigos $47^{53}$ e $1.015^{54}$ do CC/2002, $115^{55}, 117, \$ 1^{\mathrm{o}} \mathrm{C}, 158^{57}$ e $159^{58} \mathrm{da}$

52 ANTUNES, José Augusto Quelhas Lima Engrácia. Estrutura e responsabilidade da empresa: O moderno paradoxo regulatório. Revista Direito GV, São Paulo: Fundação Getúlio Vargas, v.1, n. 2, jun./dez. 2005, p. 51-52.

53 "Art. 47. Obrigam a pessoa jurídica os atos dos administradores, exercidos nos limites de seus poderes definidos no ato constitutivo."

54 "Art. 1.015. No silêncio do contrato, os administradores podem praticar todos os atos pertinentes à gestão da sociedade; não constituindo objeto social, a oneração ou a venda de bens móveis depende do que a maioria dos sócios decidir. Parágrafo único. O excesso por parte dos administradores somente pode ser oposto a terceiros se ocorrer pelo menos uma das seguintes hipóteses. I - se a limitação de poderes estiver inscrita ou averbada no registro da sociedade; II - provando-se que era conhecida do terceiro; III - tratando- se de operação evidentemente estranha aos negócios da sociedade."

55 "Art. 115. O acionista deve exercer o direito a voto no interesse da companhia; considerar-se-á abusivo o voto exercido com o fim de causar dano à companhia ou a outros acionistas, ou de obter, para si ou para outrem, vantagem a que não faz jus e de que resulte, ou possa resultar, prejuízo para a companhia ou para outros acionistas."

56 "Art. 117. O acionista controlador responde pelos danos causados por atos praticados com abuso de poder. $\$ 1^{\circ}$ São modalidades de exercício abusivo de poder: a) orientar a companhia para fim estranho ao objeto social ou lesivo ao interesse nacional, ou levá-la a favorecer outra sociedade, brasileira ou estrangeira, em prejuízo da participação dos acionistas minoritários nos lucros ou no acervo da companhia, ou da economia nacional".

57 "Art. 158. O administrador não é pessoalmente responsável pelas obrigações que contrair em nome da sociedade e em virtude de ato regular de gestão; responde, porém, civilmente, pelos prejuízos que causar, quando proceder: I - dentro de suas atribuiçôes ou poderes, com culpa ou dolo; II - com violação da lei ou do estatuto.

$\$ 1^{\circ} \mathrm{O}$ administrador não é responsável por atos ilícitos de outros administradores, salvo se com eles for conivente, se negligenciar em descobri-los ou se, deles tendo conhecimento, deixar de agir para impedir a sua prática. Exime-se de responsabilidade o administrador dissidente que faça consignar sua divergência em ata de reunião do órgão de administração ou, não sendo possível, dela dê ciência imediata e por escrito ao órgão da administração, no conselho fiscal, se em funcionamento, ou à assembleia-geral.

$\$ 2^{\circ}$ Os administradores são solidariamente responsáveis pelos prejuízos causados em virtude do não cumprimento dos deveres impostos por lei para assegurar o funcionamento normal da companhia, ainda que, pelo estatuto, tais deveres não caibam a todos eles."

58 "Art. 159. Compete à companhia, mediante prévia deliberação da assembleia-geral, a ação de responsabilidade civil contra o administrador, pelos prejuízos causados ao seu patrimônio". 
Lei n. 6.404/76, bem como art. 14 do Decreto 3.708/19 ${ }^{59}$. Em contrapartida, passa a reconhecer a existência do instituto do controle intersocietário, admitindo a subordinação da sociedade "ao poder e à influência de outra sociedade - como é o caso das controladas e controladoras (art. 243, $\$ 2^{\circ}$ da Lei n. 6.404/76), vivendo num verdadeiro paradoxo ou síndrome regulatória denominada por Antunes de "Síndrome do Cavalo de Troia"60.

Essas regras paradoxais, que de um lado preveem a autonomia de controle da sociedade e de outro autorizam sua submissão à vontade de outra sociedade "convivem "harmoniosamente" num mesmo ambiente legal, fato este que corresponde a um verdadeiro paradoxo regulatório do direito das sociedades"61.

\subsection{O poder de controle interno}

As sociedades, para que possam desenvolver a atividade empresarial, necessitam realizar uma estruturação organizacional interna que possibilite a tomada de decisões, a fim de formar e exteriorizar a vontade social. Esta estrutura, geralmente, é composta por órgãos corporativos que possuem competências próprias ditadas pela lei e pelo estatuto.

No que tange as sociedades por ações, sua estruturação interna é ditada pela Lei n. 6.404/76, que previu um modelo onde os órgãos sociais são a assembleia geral, os órgãos administrativos e o conselho fiscal. Segundo Prado

A assembleia geral tem a função de formar a vontade social em matérias fundamentais na vida da sociedade e sobre temas do seu interesse. À administração, compete exteriorizar a vontade social e travar relaçôes com terceiros. O conselho fiscal, como o próprio nome faz saber, tem competência para fiscalizar a condução dos negócios sociais $^{62}$.

A estrutura da sociedade anônima não adota, para fim de tomada de decisões, o regime democrático, segundo o qual caberia um voto para cada pessoa que inte-

\footnotetext{
59 "Art. 14. As sociedades por quotas, de responsabilidade limitada, responderão pelos compromissos assumidos pelos gerentes, ainda que sem o uso da firma social, se forem tais compromissos contraídos em seu nome ou proveito, nos limites dos poderes da gerencia."

60 HOLLANDA, Pedro Ivan Vasconcelos. Os grupos societários como superação do modelo tradicional da sociedade comercial autônoma, independente e dotada de responsabilidade limitada. Dissertação de Mestrado, UFPR, Curitiba, 2008, p. 114.

61 Ibidem, p. 115.

62 PRADO, Viviane Muller. Conflitos de interesses nos grupos societários. São Paulo: Quartier Latin, 2006, p. 80-81.
} 
•• Tributação, direitos fundamentais e desenvolvimento

grasse seu quadro societário, vigorando a regra de que para cada ação corresponde um voto. Além disto, não se exige a unanimidade na tomada de decisões, preponderando o princípio majoritário, segundo o qual cabe à maioria decidir sobre a condução dos negócios sociais.

Disto se retira que o legislador achou por bem conceder o direito de voto somente aos acionistas, pois estes se arriscaram investindo na sociedade, além do que teriam um especial interesse no desenvolvimento da atividade social.

O modelo de organização interna das sociedades por ações, bem como a adoção do princípio majoritário e da ação com poder de voto, possibilita a centralização e concentração do poder, tendo em vista que um acionista pode ser titular de quantas ações forem suficientes para possuir as rédeas dos negócios sociais ${ }^{63}$. Além disto, este modelo gera um poder de controle estável, ou seja, a titularidade do poder de formação da vontade social já é conhecida e não oscila entre os acionistas, o que esvazia o sentido de reunião em assembleia geral, sendo estas "apenas ato declaratório de uma decisão previamente definida, cuja realização tem por fim cumprir requisitos legais e legitimar a posição do acionista controlador ${ }^{64 "}$.

Nos grupos societários esta situação é ainda mais inflamada, pois cada sociedade que os integram perde, de forma total ou parcial, a sua autonomia econômica e, por conseguinte, sua autodeterminação na condução da atividade negocial da sociedade. Segundo Prado:

A existência dos grupos veio retirar qualquer dúvida da ficção do modelo legal e da função rígida dos órgãos sociais com competências não flexíveis. Apesar de o funcionamento dos grupos contrariar o modelo teórico das sociedades independentes, as legislações societárias mantêm uma estrutura obrigatória como ponto de partida para a regulamentação das sociedades por ações. (...) A concepção de grupo de sociedades está ligada à noção de controle, pois o fenômeno grupal pressupõe que uma mesma empresa tem o controle de outras sociedades. Desde logo, pode-se afirmar que, em matéria societária, o poder de controle é elemento essencial e característico ao fenômeno dos grupos de sociedade ${ }^{65}$.

A Lei n. 6.404/76 disciplina duas situações distintas em que o poder de controle é exercido. A primeira previsão está no art. 116, segundo o qual acionista controlador é a pessoa, natural ou jurídica (desde que não adote forma societária), ou grupo

\footnotetext{
Ibidem, p. 82.

64 Ibidem, p. 82-83.

65 Ibidem, p. 84.
} 
de pessoas vinculadas por acordo de voto, ou sob controle comum. Já a segunda está no art. $243, \$ 2^{\circ}$ da mesma Lei, que incide quando o controlador for uma sociedade.

Segundo o art. 243, que interessa a este trabalho, a sociedade somente poderá ser chamada de controladora se, simultaneamente, reunir três requisitos: "1. Ser sócia direta ou indiretamente da controlada; 2 . Deter maioria dos votos nas assembleias, de modo permanente; e 3. Eleger a maioria dos administradores ${ }^{66 "}$.

O primeiro requisito demonstra a opção da Lei n. 6.404/76 em considerar somente o controle que decorre da participação no capital social da controlada. $\mathrm{O}$ segundo requisito demonstra a adoção do princípio majoritário e do poder de controle estável, pois somente pode deter o controle aquele que detém o poder de decisão através da maioria das ações. Já em relação ao terceiro requisito, mesmo havendo divergência doutrinária se esta exigência deve ser cumulativa ou não, certo é que a lei exige, pelo menos, um poder potencial de eleger a maioria dos administradores, pois este estaria implícito àquele que detém a maioria dos votos nas deliberações assembleares ${ }^{67}$.

Em suma, o poder de controle é elemento essencial para a configuração do fenômeno grupal e apesar de não estar sozinho na configuração de um grupo societário, pois como já dito anteriormente, a direção unitária deve estar a ele conjugada, dele decorre toda a problemática dos grupos societários de fato, tendo em vista que, na maioria esmagadora dos casos o controle é exercido com conflito de interesses ou abuso de poder.

A maleabilidade do controle interno, que lhe proporciona a manifestação através de variadas formas ${ }^{68}$ representa o ambiente propício para a formação dos grupos societários. Neste sentido, os grupos "desmistificam o dogma da autonomia da sociedade comercial"69, pois, estando o poder fora da estrutura dos órgãos sociais, a vontade grupal acaba por ficar comprometida aos vários interesses sociais agrupados. Hollanda muito bem assevera a questão ao explicitar que:

${ }^{66}$ Ibidem, p. 95.

${ }^{67}$ PEREIRA, Guilherme Döring Cunha. Alienação do poder de controle acionário. São Paulo: Saraiva, 1995, p. 18.

68 Berle e Means (Nova Iorque - 1932) distinguem entre cinco diferentes formas de controle, como: "1) controle através da propriedade quase total; 2) controle majoritário; 3) controle através de um dispositivo legal sem propriedade majoritária; 4) controle minoritário; e 5) controle administrativo". Fabio Konder Comparato (Rio de Janeiro - 1983) reduz a quatro tipos de controle interno: totalitário, majoritário, minoritário e gerencial.

69 HOLLANDA, Pedro Ivan Vasconcelos, op. cit., p. 122. 
•• Tributação, direitos fundamentais e desenvolvimento

$\mathrm{Na}$ sociedade anônima, dada a própria natureza de sua constituição - pois lhe é possível ter milhares de acionistas proprietários e, ao mesmo tempo, ser dirigida por pessoas que sequer detêm parte de sua propriedade -, é inerente o conflito entre os mais variados rumos que os seus proprietários pretendem lhe proporcionar, situação essa que se exponencia frente aos grupos societários, nos quais a unidade econômica que lhe é característica faz com que toda e qualquer barreira eventualmente criada pelas autonomias de cada sociedade que lhe compõe seja transposta para o atendimento do comando existente no grupo ${ }^{70}$.

\subsubsection{A direção unitária}

Como já expressado anteriormente, a direção unitária é um dos elementos que conferem o caráter de grupo a distintas sociedades. Como explicita Viviane Muller Prado, "o conceito de direção unitária relaciona-se com a situação econômica das empresas, com a forma do exercício do poder de controle e da influência da sociedade dominante sobre a dependente" 71 .

Primeiramente, a sua relação com a situação econômica das empresas agrupadas ocorre por ser a direção unitária o elemento que dará unidade econômica ao grupo, através da transferência das atribuições de gestão empresarial para a sociedade controladora. A integração de uma sociedade a um grupo societário faz com que aquele ente dotado de autodeterminação na condução de suas atividades perca sua independência econômica originária, transferindo-a para a sociedade de comando do grupo.

A associação da direção unitária com a forma de exercício do poder de controle é outro ponto fundamental da discussão, tendo em vista que a existência da relação de controle não pressupõe necessariamente a relação grupal. "O fim da atividade de direção unitária exercida pela controladora do grupo consiste na organização e valorização econômica do controle sobre uma pluralidade de sociedades. Assim, o controle exercido sem que se pretenda a unidade e coordenação não é capaz de configurar uma relação grupal.

Por fim, é preciso realizar a análise da correlação entre a direção unitária e a questão da influência dominante. A ideia de influência dominante está relacionada a uma situação de dependência entre a sociedade controladora e a controlada. A doutrina entende de forma pacífica que não é essencial para a formação do grupo

\footnotetext{
Ibidem, p. 122.
}

71 PRADO, Viviane Muller. Conflitos de interesses nos grupos societários. São Paulo: Quartier Latin, 2006, p. 113. 
a existência de dependência, haja vista existirem não só grupos de subordinação, mas também de coordenação. Nestes, a direção unitária é exercida de forma consensual, não havendo subordinação, ao passo que naqueles a direção unitária é imposta. Assim, é possível concluir que pode existir grupo sem dependência, mas não sem direção unitária.

Os grupos de fato que são objeto deste trabalho são aqueles em que está presente o elemento da subordinação, ou seja, são os grupos de fato por subordinação, razão pela qual não há como se dissociar a figura da influência dominante da direção unitária. Isto porque, nestes grupos a direção unitária é imposta pela sociedade controladora às demais sociedades agrupadas, em decorrência do exercício da influência dominante. Nas palavras de Viviane Muller Prado estes grupos são identificáveis quando

em uma relação de dependência entre sociedades, o conjunto forma um todo no qual se pode observar a ligação que vai além do simples exercício do controle. (...) O fim da atividade de direção unitária exercida pela controladora do grupo consiste na organização e valorização econômica do controle sobre uma pluralidade de sociedades ${ }^{72}$.

Porém, após esta explanação, retorna-se ao ponto crucial deste capítulo. Como convivem a direção unitária e coordenada das atividades da controladora com a organização interna das sociedades controladas, tendo em vista que "nos grupos de fato não pode a sociedade controladora impor diretrizes às demais, como nos grupos convencionais"73? Segundo Prado:

A organização grupal deve respeitar os limites impostos pela lei societária, que tem uma visão da sociedade isolada. O exercício do poder de controle é limitado pela regra do conflito de interesses e do não abuso do poder de controle, impedindo auferir vantagem para si ou para outra sociedade em detrimento da controlada. O controlador, portanto, ainda que exerça o seu poder para dar unidade econômica às várias sociedades da qual participa, deve levar em conta o interesse de cada uma delas ${ }^{74}$.

\subsubsection{Conflito de interesse e abuso de poder}

A realidade empresarial contemporânea do Brasil, no que tange a parcela que objetiva negócios de larga escala e forte impacto na esfera mundial, como já explicitado, é majoritariamente formada por grupos societários. Estas formaçōes grupais se configuram como um conjunto de sociedades que mantêm sua personalidade

\footnotetext{
Ibidem, p. 158.

Ibidem, p. 158.

$74 \quad$ Ibidem, p. 158.
} 
•• Tributação, direitos fundamentais e desenvolvimento

jurídica, mas que estão sob um controle comum, exercido para coordenar as atividades e as decisóes das sociedades controladas, elemento que as confere uma unidade econômica. Por isso, diz-se que os grupos representam uma unidade econômica em uma diversidade jurídica.

Desta situação paradoxal resultante da combinação de unidade e diversidade em uma mesma estrutura se observa que "a constituição de um grupo de sociedades pressupõe o atingimento, por todos os seus integrantes, de um único objetivo empresarial ou de vários objetivos que entre si sejam convergentes e de acordo com o interesse do grupo.75 Os interesses da sociedade controladora que extrapolam aqueles decorrentes de sua posição de sócia, na busca pelo interesse do grupo, consubstanciam-se através do exercício do poder de controle. Segundo Prado esse poder exercido pelo controlador pode ser vislumbrado:

Pela sua atuação em assembleia geral, na escolha dos administradores, bem como com a sua influência nos órgãos administrativos das controladas. Em consequência disso, a assembleia geral da controladora e seus órgãos administrativos tornam-se órgãos centrais e fundamentais para todas as sociedades do grupo ${ }^{75}$.

Apesar disto, deve-se ter em mente que a participação de uma sociedade em um grupo societário não retira dela sua personalidade jurídica e demais características resultantes de sua independência. A partir do dogma da autonomia econômica da sociedade comercial é que se retira o sentido existencial das regras estabelecidas para limitar a atuação dos controladores e administradores.

A sociedade anônima é a protagonista na formação dos grupos econômicos, como foi explicitado no início deste trabalho, em decorrência de suas diversas características que favorecem a formatação grupal. Dentro de uma sociedade isoladamente considerada já existe uma grande realidade de conflito de interesses, tendo em vista que sua composição é formada, geralmente, por diversos acionistas. No tocante aos grupos societários, Hollanda traz uma importante colocação ao dizer que:

Tal conflituosidade de interesses ganha ainda maior proporção ao se transportar essa discussão àquela mantida entre as variadas sociedades componentes de um grupo societário de subordinação, as quais, igualmente, possuem seus acionistas com interesses das mais variadas ordens. Assim, o grupo de sociedades representa um turbilhão de vontades e de interesses que exponencia ao grau máximo o conflito de interesses que pode existir apenas numa única sociedade anônima.

PRADO, Viviane Muller. Conflitos de interesses nos grupos societários. São Paulo: Quartier Latin, 2006, p. 161. 
A Lei n. 6.404/76 ao disciplinar, em seu art. 115, caput e $\$ 1^{\circ}$, a regra do conflito de interesses e do exercício abusivo do poder de controle, o faz direcionada à sociedade anônima isoladamente considerada, "como se sobre ela não fosse incidente qualquer forma de controle que lhe retirasse sua soberania ${ }^{76}$. Segundo a dicção do referido artigo, in verbis:

Art. 115. O acionista deve exercer o direito a voto no interesse da companhia; considerar-se-á abusivo o voto exercido com o fim de causar dano à companhia ou a outros acionistas, ou de obter, para si ou para outrem, vantagem a que não faz jus e de que resulte, ou possa resultar, prejuízo para a companhia ou para outros acionistas.

$\$ 1^{\circ}$ o acionista não poderá votar nas deliberações da assembleia-geral relativas ao laudo de avaliação de bens com que concorrer para a formação do capital social e à aprovação de suas contas como administrador, nem em quaisquer outras que puderem beneficiá-lo de modo particular, ou em que tiver interesse conflitante com o da companhia.

Daí surge a indagação se seria possível a aplicação desta regra também às sociedades controladoras, já que o artigo fala somente em acionista. A conclusão mais acertada seria aquela que admite a aplicação da regra do conflito de interesses e do abuso do poder de voto aos grupos societários, mais precisamente os de fato, aplicando-se uma interpretação sistemática da Lei em apreço. Muito bem assevera Hollanda ao explicitar que

o alcance da discussão sobre o conflito de interesses e abuso no direito de voto aos grupos societários pode ocorrer na medida em que a redação dada ao artigo $115 \mathrm{da}$ Lei das Sociedades Anônima é aplicável a todo o qualquer acionista, inclusive àquele que exerce o poder de controle sobre a companhia. Assim, considerando-se que nos grupos societários (de fato) é imprescindível a figura do acionista controlador, representado por uma sociedade, conforme dispóe o artigo $243, \$ 2^{\circ}$ da lei mencionada, tal sujeito também deve se submeter aos preceitos contidos no referido artigo 115. Assim, a interpretação que parece mais adequada ao caso consiste em se admitir que no conceito de acionista controlador está o de sociedade controladora, a ela se aplicando as previsões contidas nos artigos 115, 116 e 117 da Lei das Sociedades Anônimas ${ }^{77}$.

Através desta interpretação, a sociedade controladora está impossibilitada de exercer o poder de controle em um grupo societário de fato em desacordo com os interesses das sociedades controladas. Porém, como bem indagado por Prado, “é própria da situação de agrupamento de empresas a interposição de interesses

76 HOLLANDA, Pedro Ivan Vasconcelos, op. cit., p. 144.

77 HOLLANDA, Pedro Ivan Vasconcelos, op. cit., p. 145-146. 
•• Tributação, direitos fundamentais e desenvolvimento

estranhos aos da sociedade ${ }^{78 "}$, de forma que a autora conclui ser uma "ingenuidade" legislativa a exigência de neutralidade por parte do controlador, pois para que isso acontecesse de fato, ele teria que traçar uma "muralha da China imaginária nos seus negócios"79.

A regra sobre conflito de interesses e abuso do poder prevista na Lei acionária é direcionada a evitar um conflito esporádico, ou seja, que ocorreria eventualmente na vida societária. Porém, a regra encontra nos grupos societários de fato um conflito institucionalizado, o que provoca um questionamento sobre a efetividade da aplicação de tais regras à realidade empresarial brasileira.

\subsection{A (in)dependência ${ }^{80}$ da pessoa jurídica}

Já tendo sido analisada a questão da autonomia de controle da sociedade comercial, passa-se à discussão sobre a independência da pessoa jurídica frente a sua inserção em um grupo societário.

A disciplina do direito societário está sedimentada na concepção de sociedade comercial como um ente juridicamente autônomo, dotado de interesses, responsabilidades e patrimônios próprios, capaz de construir sua vontade social no interior de suas próprias estruturas, sem que sofra a influência de vetores externos. Esta ideia de independência é possível a partir do instituto da pessoa jurídica, através do qual a sociedade comercial recebe sua personalidade jurídica se regularmente inscrita.

A concessão de personalidade jurídica a uma coletividade faz com que esta se torne uma unidade jurídica, reconhecidamente travestida no papel de sujeito de direito dotado de independência organizacional e patrimonial. Sendo, então, a pessoa jurídica sujeito de direito, ela tem interesses próprios que devem ser observados e respeitados por seus membros.

A questão não parece controversa ao se analisar o direito societário não grupal. Porém, ao se adentrar no campo das formações grupais a questão se torna turbulenta. Isto porque, os grupos societários, como já explicitado, são uma unidade econômica em uma pluralidade jurídica, ou seja, apesar das sociedades terem se

78 PRADO, Viviane Muller. Conflitos de interesses nos grupos societários. São Paulo: Quartier Latin, 2006, p. 163.

79 Ibidem, p. 164.

80 HOLLANDA, Pedro Ivan Vasconcelos, op. cit., p. 149. 
unido buscando o atingimento de uma finalidade empresária comum através de uma direção e coordenação unitária, elas conservam suas personalidades jurídicas intactas, privilegiando a independência resultante de sua personificação.

O grande "porém" está no fato de que ao aceitarem uma direção e coordenação unitária que busque a realização dos interesses do grupo, as sociedades controladas abrem mão parcialmente ou, até, totalmente de sua autonomia, passando a serem meros instrumentos da sociedade controladora.

Diante deste quadro, Hollanda expõe que é nos grupos societários onde ocorre o encontro entre as duas crises da pessoa jurídica, como pode se observar pelo seguinte trecho:

(...) os grupos societários são focos tanto da crise de estrutura como da crise de função. De estrutura, porque é de se questionar se à figura dos grupos de sociedade é possível conceber-se personalidade jurídica, tendo em vista que esses atuam verdadeiramente como sujeitos econômicos (empresas), por mais que sejam dotados das mais variadas formas societárias. De função, pois o controle exercido por uma sociedade em outra no mesmo grupo, faz com que a controlada perca a autonomia e independência que lhe é inerente ao ser constituída, passando a exercer apenas a função de mero instrumento ou departamento da sociedade dominadora, refutando-se, assim, a autonomização do ente coletivo ${ }^{81}$.

Segundo o autor, estas crises podem ser constatadas tanto pela perspectiva das sociedades controladas como pelas sociedades controladoras. Na perspectiva da sociedade controlada, observa-se uma crise de função pela perda de sua autonomia em decorrência do comando exercido pela sociedade controladora. Já pela ótica da sociedade- mãe, constata-se uma crise de estrutura, uma vez que a assunção desta posição provoca na sociedade um "insuflamento de suas estruturas, de sua organização, administração e de suas responsabilidades, constituindo-se assim uma sociedade hipertrofiada" 82 .

A perda da autonomia das sociedades que compõem um grupo societário é algo claro e inerente ao funcionamento dos grupos. Diante disto, a fim de possibilitar que os grupos empresariais cumpram a sua relevante função dentro da economia, Prado propóe que o legislador elabore regras especificas, direcionadas às pessoas jurídica dependentes, em vista de suas peculiares características em relação à noção tradicional de autonomia. Segundo a autora:

81 HOLLANDA, Pedro Ivan Vasconcelos, op. cit., p. 164.

82 Ibidem, p. 164. 
•• Tributação, direitos fundamentais e desenvolvimento

Cabe ao legislador estabelecer mecanismos que aceitem a alteração no processo de construção da vontade do ente coletivo, a fim de assegurar a integridade patrimonial da pessoa jurídica à proteção de interesses relacionados, e criar limites no exercício do poder e na autonomia de vontade, na organização interna ${ }^{83}$.

Porém, dada a devida vênia ao entendimento da brilhante autora, a criação de um novo tipo de pessoa jurídica não é o caminho mais interessante para solucionar o problema da subordinação da sociedade. A existência legislativa de uma pessoa jurídica dependente exige que toda a doutrina societária tradicional sofre uma reconstrução, sem que traga a garantia de que solucionaria o problema dos grupos societários. Além disso, ao se reconhecer a dependência, abre-se um espaço fértil para fraudes, uma vez que dificilmente o legislador delimitaria de forma precisa os limites desta dependência.

\section{RESPONSABILIDADE DAS EMPRESAS INTEGRANTES DE GRUPO SOCIETÁRIO: LACUNA NO DIREITO SOCIETÁRIO E TRIBUTÁRIO}

No capítulo anterior do presente trabalho, foram abordados dois dos três principais elementos que formam as sociedades comerciais segundo a teoria do direito societário tradicional, quais sejam, a autonomia societária e a independência jurídica da sociedade. Juntamente com estes dois elementos, a responsabilidade limitada corresponde pressuposto intrínseco à doutrina do direito societário aplicada as sociedades limitas e anônimas.

A responsabilidade limitada significou importante incentivo ao desenvolvimento dos institutos societários-mercantis em meados do século XVII, pois encorajava aqueles que possuíam interesse em investir nas expediçôes ultramarinas, principal atividade comercial da época e que possuía alto risco de insucesso.

No direito brasileiro, a sociedade anônima somente terá a responsabilidade limitada após a sua personalização jurídica. Esta não existindo, a responsabilidade será ilimitada, como ocorre nas sociedades em comum ${ }^{84}$ e nas sociedades em conta de participaçãoo ${ }^{85}$. Neste diapasão, sendo praticado algum ato em descompasso com

83 PRADO, Viviane Muller. Conflitos de interesses nos grupos societários. São Paulo: Quartier Latin, 2006, p. 173.

84 Código Civil, Art. 990. Todos os sócios respondem solidária e ilimitadamente pelas obrigaçóes sociais, excluído do benefício de ordem, previsto pelo art. 1.024, aquele que contratou pela sociedade.

85 Código Civil, Art. 991. Na sociedade em conta de participação, a atividade constitutiva do objeto social é exercida unicamente pelo sócio ostensivo, em seu nome individual e sob sua 
a lei ou o estatuto, através de abuso da personalidade jurídica, desvio de finalidade social e confusão patrimonial, é aplicada a teoria da desconsideração da personalidade jurídica, desconstruindo-se a noção de limitação de responsabilidade daqueles que integram a sociedade e atingindo diretamente seu patrimônio.

A questão em foco ganha importante relevância quando se passa a analisá-la não mais através dos holofotes do regramento direcionado às sociedades comerciais dotadas de autonomia e independência jurídica, mas a desloca para o grande vazio regulatório oferecido aos grupos empresariais, como bem assevera Hollanda:

Diferentemente é o trato do assunto quando se está diante dos grupos de sociedade, como nos centralizados e dotados de subordinação, em que estabelecida uma relação de controle e de dependência pela sociedade-mãe sobre as suas sociedades-filhas. Nesse caso, a tradicional limitação da responsabilidade na sociedade comercial fica estremecida e relativizada, pois não se verificam os mesmos substratos à sua regular aplicação ${ }^{86}$.

A partir disto, o autor ainda elabora importantes indagações, que servirão para balizar os próximos tópicos do trabalho:

Afinal, uma sociedade-filha, dependente e controlada por uma sociedade-mãe é limitadamente responsável pelas obrigaçōes que contrair a mando de sua controladora? Tais responsabilidades poderão ser erigidas frente à sociedade- mãe em razão dessa ter se utilizado de sua controlada para o atingimento de seus próprios interesses? Trata-se de se aplicar, nesses casos, a teoria da desconsideração da personalidade jurídica perante os grupos de sociedades para que se alcance a responsabilização da sociedade controladora? A sociedade controladora é sempre responsável pelos débitos de sua sociedade controlada nas hipóteses em que essa última seja utilizada para o atingimento dos fins do grupo societário ${ }^{27}$

As perguntas formuladas pelo autor são extremamente importantes, ao mesmo tempo que profundamente complexas. Porém, nos próximos tópicos deste trabalho busca- se o esclarecimento de algumas destas indagações, que servirão para se alcançar conclusões importantes sobre o tema abordado.

\subsection{A responsabilidade e grupos societários}

Ao se estudar os grupos societários, observa-se que a questão mais sensível e tormentosa sobre o tema é a parte que trata da responsabilidade, isto porque a

própria responsabilidade, participando os demais dos resultados correspondentes. Parágrafo único. Obriga-se perante terceiro tão somente o sócio ostensivo; e, exclusivamente perante este, o sócio participante, nos termos do contrato social.

86 HOLLANDA, Pedro Ivan Vasconcelos, op. cit., p. 168-169.

87 Ibidem, p. 169. 
•• Tributação, direitos fundamentais e desenvolvimento

questão é pouco estudada e, por conseguinte, o jurista esbarra em conceitos ainda pouco enfrentados pela doutrina.

A teoria tradicional do direito societário pouco ajuda no estudo, pois os grupos societários atingiram uma complexidade tal que ela não conseguiu alcançá-los. Porém, seus conceitos fundamentais servem como ponto de partida para que se possa visualizar um caminho à elaboração de estudo sobre a responsabilidade nos grupos.

A responsabilidade limitada nas sociedades comerciais é aplicada segundo o binômio poder/responsabilidade. Isto quer dizer que aquele que não tem o poder de comandar a sociedade não pode responder pelos atos praticados por aqueles que detém a competência para o comando. Neste sentido, muito bem asseverou Antunes ao dizer que "se, positivamente a um poder ilimitado deve corresponder uma responsabilidade limitada (...), então, também, negativamente, a um poder limitado deverá corresponder uma responsabilidade limitada" ${ }^{88}$.

Este binômio, utilizado na prática, serve para determinar que o simples acionista da companhia responde de forma limitada, por não exercer qualquer poder de direção na sociedade anônima. Assim como ocorre com os sócios quotistas nas sociedades limitadas. Mesmo os administradores, seja da sociedade anônima ou da sociedade limitada, somente responderão ilimitadamente quando praticarem atos em desconformidade com a lei ou com o estatuto social ${ }^{89}$.

Deslocando-se a análise da sociedade comercial individualizada, isolada, autônoma e independente e passando agora a analisar os grupos societários, onde se observa uma relação de subordinação entre sociedades e de centralização do poder de comando em uma sociedade-mãe, "a discussão sobre a limitação da responsabilidade se desloca do seu habitat natural"90.

Nos grupos de sociedade a discussão sobre a limitação da responsabilidade é fortemente influenciada pela separação entre a propriedade e o controle, que ocorre

Ibidem, p. 170 apud ANTUNES, José Engrácia. Estrutura e responsabilidade da empresa, p. 34.

89 Art. 1.016. Os administradores respondem solidariamente perante a sociedade e os terceiros prejudicados, por culpa no desempenho de suas funçôes.

Art. 158. O administrador não é pessoalmente responsável pelas obrigações que contrair em nome da sociedade e em virtude de ato regular de gestão; responde, porém, civilmente, pelos prejuízos que causar, quando proceder: I - dentro de suas atribuições ou poderes, com culpa ou dolo; II - com violação da lei ou do estatuto.

Art. 117. O acionista controlador responde pelos danos causados por atos praticados com abuso de poder.

90 HOLLANDA, Pedro Ivan Vasconcelos, op. cit., p. 170. 
A responsabilidade tributária das sociedades integrantes de grupos econômicos de fato

como resultado da própria formação estrutural do grupo, através da perda de autonomia organizacional, patrimonial e jurídica das sociedades que o compõem, em privilégio ao controle, domínio e interesses da sociedade dominadora. Segundo Hollanda:

a partir do momento em que se estabelece uma relação de grupo entre sociedades -, mais especialmente num grupo de fato, nos termos do artigo $243, \S 2^{\circ}$, da Lei 6.404/76, dotado de centralização e subordinação entre seus entes - diversas sociedades autônomas, independentes juridicamente e com uma estrutura organizacional própria são reunidas para formar um ente de natureza econômica destinado ao atendimento dos objetivos preconizados pela sociedade dominante. Trata-se da já repetidas vezes mencionada "unidade econômica numa diversidade jurídica". As sociedades dominadas servem, portanto, como instrumentos para o atendimento do fim colimado por sua dominante, atuando como se dela fossem meras prepostas ${ }^{91}$.

Neste diapasão, apesar das sociedades controladas não mais possuírem plena autonomia decisional, a lei determina que são mantidas suas independências jurídicas $^{92}$ e, consequentemente, suas responsabilidades limitadas. Esta situação heterogênea é resultado de uma disciplina incompleta oferecida pela Lei do anonimato sobre os grupos societários, uma vez que ela conserva a independência jurídica das sociedades filiadas, sem prever qualquer tipo de disciplinamento específico sobre a responsabilização, resultando na aplicação da teoria tradicional que não é, no caso dos grupos, nem um pouco favorável aos credores.

A preservação da personalidade jurídica e da limitação da responsabilidade das sociedades controladas funciona, na prática, como uma blindagem ao atingimento do verdadeiro comando da atividade empresarial, exercido pela sociedade dominadora. As controladas passam a responder pelos riscos das atividades empresarias apetecidas pela controladora do grupo. Nas palavras de Hollanda, "a sociedade controladora imune aos riscos, exerce um verdadeiro "direito à irresponsabilidade" "'93.

No início deste tópico, falava-se no binômio poder/responsabilidade como justificação da responsabilidade limitada nas sociedades comerciais. Pois bem, nos grupos societários esta lógica é descaracterizada, uma vez que aquele que possui o poder de comandar está “isento” de responsabilidade, sendo esta suportada pela

91 HOLLANDA, Pedro Ivan Vasconcelos, op. cit., p. 171.

92 Art. 266. As relações entre as sociedades, a estrutura administrativa do grupo e a coordenação ou subordinação dos administradores das sociedades filiadas serão estabelecidas na convenção do grupo, mas cada sociedade conservará personalidade e patrimônios distintos.

93 HOLLANDA, Pedro Ivan Vasconcelos, op. cit p. 172. 
•• Tributação, direitos fundamentais e desenvolvimento

sociedade controlada. Hollanda penetra mais profundamente no tema ao expor o seguinte:

nos grupos societários, verifica-se que as estruturas de comando das sociedades controladas acabam por serem desfiguradas, pois passam suas assembleias ordinárias a serem apenas meros atos de formalidade legal, tendo em vista o expresso cumprimento das orientações da sociedades comandante. Ocorre a transferência dos "poderes de governo e supervisão do colégio de sócios” das sociedades-filhas para a sociedade-mãe, o que leva ao insuflamento de poderes do seu órgão de administração ${ }^{94}$.

Deste cenário conturbado, é que surgem os mais diversos conflitos relacionados aos grupos societários, como é o caso da questão tributária sobre a responsabilidade pelo pagamento do tributo. O grande problema é que os grupos societários de fato não são suficientemente regulados, ficando a sua disciplina, salvo poucas exceçōes, a cargo das regras direcionadas às sociedades isoladas, o que causa esta grande desorientação jurídica, deixando a cargo de cada ramo do direito tutelar apartadamente seus conflitos naquilo que tangenciam conflituosamente com os grupos societários.

\subsection{A legislação acerca da responsabilidade nos grupos societários e a lacuna do direito tributário}

A Lei n. 6.404/76 se absteve, como já dito anteriormente, de prever regras sobre responsabilidade em seu texto, o que se observa pela leitura da Exposição de Motivos $^{95}$, que não foi uma falha do legislador, mas sim uma vontade consciente do mesmo. $\mathrm{Na}$ Exposição é possível observar que o legislador presumia que os credores exigiriam a responsabilidade solidária em contrato firmado com o grupo, caso assim fosse de sua vontade. Além do que, para ele, a imposição de responsabilidade solidária desvirtuaria o instituto do grupo societário.

Claro que estes argumentos não se mostram nem um pouco convincentes na prática. Primeiro, porque seria muita ingenuidade se esperar que um credor de um

HOLLANDA, Pedro Ivan Vasconcelos, op. cit p. 174.

95 "No artigo 267, o Projeto absteve-se de criar a responsabilidade solidária presumida das sociedades do mesmo grupo, que continuam a ser patrimônios distintos, como unidades diversas de responsabilidade e risco, pois a experiência mostra que o credor, em geral, obtém a proteção dos seus direitos pela via contratual, e exigirá solidariedade quando o desejar. Ademais, tal solidariedade, se estabelecida em lei, transformaria as sociedades grupadas em departamentos da mesma sociedade, descaracterizando o grupo, na sua natureza de associação de sociedades com personalidade e patrimônio distintos.” 
A responsabilidade tributária das sociedades integrantes de grupos econômicos de fato

grupo econômico de fato exigisse em contrato a responsabilidade solidária, tendo em vista que ele, muitas vezes, nem sabe que existem empresas agrupadas. Mesmo nos raros grupos de direito é forçoso acreditar que se firmaria algum contrato em que houvesse previsão expressa de responsabilização solidária das sociedades agrupadas.

Além disto, o segundo argumento apresentado pelo legislador de que a previsão da solidariedade provocaria o desvirtuamento do instituto do grupo societário, transformando "as sociedades grupadas em departamentos da mesma sociedade", acaba sendo o que acontece na prática, principalmente nos grupos de fato. $\mathrm{O}$ legislador procurou somente prever no texto da Lei n. 6.404/76 as situações que favorecessem a constituição dos grupos, afastando aquilo que pudesse coibi-la, como é o caso da responsabilização.

A partir deste cenário, diferentes ramos do Direito, como o trabalhista e o consumerista, não permaneceram inertes, prevendo em seus regimes jurídicos dispositivos de responsabilização solidária ou subsidiária das sociedades integrantes de grupos societários.

O Direito do Trabalho é o campo jurídico que de forma mais clara e direta positivou a responsabilização solidária das empresas agrupadas para efeitos da relação de emprego, oferecendo um detalhamento que não se encontra em outros ramos, como se observa pela leitura do art. $2^{\circ}, \$ 2^{\circ}$ da Consolidação das Leis do Trabalho, in verbis:

Art. $2^{\circ}, \$ 2^{\circ}$ Sempre que uma ou mais empresas, tendo, embora, cada uma delas, personalidade jurídica própria, estiverem sob a direção, controle ou administração de outra, constituindo grupo industrial, comercial ou de qualquer outra atividade econômica, serão, para os efeitos da relação de emprego, solidariamente responsáveis a empresa principal e cada uma das subordinadas.

O Código de Defesa do Consumidor adotou a responsabilidade subsidiária das sociedades filiadas em grupos. Assim, o consumidor deverá obedecer ao benefício de ordem, demandando primeiramente do infrator e somente, em caso deste não poder arcar com a responsabilização, demandar das demais sociedades, segundo a dicção do art. 28, $\$ 2^{\circ}$ do referido diploma legal, in verbis:

Art. $28, \$ 2^{\circ}$ As sociedades integrantes dos grupos societários e as sociedades controladas, são subsidiariamente responsáveis pelas obrigações decorrentes deste código.

A Lei n. 12.529/11 no campo da defesa da concorrência, mantendo o que já previa a revogada Lei 8.884/94, dispõe, em seu Art. 33, no sentido de responsabilizar 
•• Tributação, direitos fundamentais e desenvolvimento

solidariamente as empresas agrupadas em grupos societários de fato ou de direito, quando pelo menos uma delas pratica infração à ordem econômica, in verbis:

Art. 33. Serão solidariamente responsáveis as empresas ou entidades integrantes de grupo econômico, de fato ou de direito, quando pelo menos uma delas praticar infração à ordem econômica.

Por fim, a Lei 8.212/91, que dispõe sobre a seguridade social, estabelece, em seu Art. 30, IX a responsabilidade solidária das empresas integrantes de grupo societário de qualquer natureza pelo pagamento das obrigações devidas à Seguridade Social, in verbis:

Art. 30. A arrecadação e o recolhimento das contribuições ou de outras importâncias devidas à Seguridade Social obedecem às seguintes normas:

IX - as empresas que integram grupo econômico de qualquer natureza respondem entre si, solidariamente, pelas obrigações decorrentes desta Lei;

A partir do dispositivo acima exposto, é possível perceber que a Lei é clara ao estabelecer a responsabilidade direta e solidária das sociedades agrupadas em relação aos débitos previdenciários, e somente em relação a estes. Desta forma, o Fisco não encontra maiores problemas em sua cobrança, justamente porque a citada Lei acabou por arrolhar a lacuna existente.

Porém, o mesmo não ocorre com os demais créditos tributários, pois nem no Código Tributário Nacional, nem em nenhuma outra lei tributária é previsto qualquer tipo de responsabilização no que concerne aos grupos societários. Há, portanto, uma lacuna no tocante ao assunto, causadora de grande insegurança jurídica e de combates infindáveis entre o Fisco e os grupos societários, que acabam encontrando diferentes elucidaçōes por parte do judiciário.

Esta lacuna é responsável por impedir que grandes vultos de dinheiro, que seriam devidos ao Estado, deixem de penetrar nos cofres públicos, ao passo que proporciona uma lucratividade cada vez maior para os grandes conglomerados nacionais, que se utilizam desta brecha do direito societário e tributário em seu favor.

A responsabilidade limitada das sociedades controladas, como já dito anteriormente, serve como blindagem para as grandes sociedades controladoras, que aparelham o grupo a fim de, propositalmente, fazer com que somente as controladas assumam débitos com o Fisco. Neste diapasão, as Procuradorias responsáveis por defenderem o crédito tributário do Estado tentam, através de diferentes teses, impedir que tal situação ocorra, buscando, de alguma forma, atingir a sociedade que verdadeiramente está saudável para pagar o tributo, como se verá a seguir. 
A responsabilidade tributária das sociedades integrantes de grupos econômicos de fato

\subsubsection{Teses utilizadas pelo Fisco para a proteção do crédito tributário no caso dos grupos societários}

\subsubsection{Da solidariedade de fato do art. 124 , I do CTN}

A solidariedade é um instituto que nasceu no direito privado e foi importado pelo direito púbico. O direito tributário, ao introduzir o instituto, conferiu-lhe certas peculiaridades próprias do direito público, impossibilitando que a solidariedade decorra de manifestação de vontade das partes, hipótese que é autorizada pelo direito privado, e, também, vedando a existência de solidariedade ativa, situação existente no direito privado.

Em matéria tributária, o instituto é muito utilizado para atender a atividade administrativa de arrecadação do Estado, tornando-a mais cômoda e eficiente. Havendo solidariedade, o credor público possui o direito subjetivo de cobrar a totalidade da dívida de qualquer um dos devedores ou de todos, simultaneamente ou sucessivamente ${ }^{96}$.

O Código Tributário Nacional disciplina, em seu art. 124, a responsabilidade tributária solidária, in verbis:

Art. 124. São solidariamente obrigadas:

I - as pessoas que tenham interesse comum na situação que constitua o fato gerador da obrigação principal;

II - as pessoas expressamente designadas por lei.

Parágrafo único. A solidariedade referida neste artigo não comporta benefício de ordem.

O indigitado artigo cuida de duas espécies de responsabilidade tributária, quais sejam, a responsabilidade solidária de fato, em seu inciso I, que é aquela proveniente do interesse comum na situação que constitua o fato gerador da obrigação e a responsabilidade solidária de direito, em seu inciso II, que é a decorrente de expresso mandamento legal.

O legislador complementar, através do art. 124 do CTN, quis ele mesmo criar uma causa para a instauração de vínculo de solidariedade entre sujeitos passivos tributários (inciso I), ao mesmo tempo que outorgou a possibilidade de fixação em lei de outras situações fáticas que determinem também a solidariedade. A partir

96 DARZÉ, Andréa Medrado. Responsabilidade tributária solidária. Breves considerações sobre os artigos 124 e 125 do Código Tributário Nacional. In: FREIRE, Elias Sampaio; DIAS, Karem Jureidini; QUEIROZ, Mary Elbe (Coord.). Grandes questôes em discussão no CARF. São Paulo: FocoFiscal, 2014, p. 31-32. 
•• Tributação, direitos fundamentais e desenvolvimento

disto é possível concluir que o interesse comum, por si só, já é uma causa de solidariedade, não necessitando de previsão legal e autorizando o Fisco a imputar a solidariedade diretamente.

A solidariedade de fato, ponto crucial da argumentação do Fisco, abriga dúvidas que atormentam a comunidade científica, principalmente por comportar em sua definição a expressão "interesse comum", carregada de imprecisão e abstratividade, sendo sua utilização massivamente criticada, como se vê do posicionamento de Paulo de Barros Carvalho:

O interesse comum dos participantes na realização do fato jurídico tributário é o que define, segundo o inc. I, o aparecimento da solidariedade entre os devedores. A expressão empregada, sobre ser vaga, não é um roteiro seguro para a identificação do nexo que se estabelece entre os devedores da prestação tributária. (...) o interesse comum dos participantes do acontecimento factual não representa um dado satisfatório para a definição do vínculo da solidariedade ${ }^{97}$.

Em meio a todo tipo de discussão acerca do significado da expressão interesse comum, o Fisco se utiliza da solidariedade de fato para justificar o lançamento do crédito tributário ou a cobrança da dívida tributária contra todas as empresas integrantes do grupo societário de fato, defendendo que é indiscutível o interesse de toda e qualquer pessoa jurídica agrupada nos atos de qualquer outra integrante, principalmente nos que beneficiem todo o agrupamento. $\mathrm{O}$ interesse comum seria justificado pela unidade de controle direcionado a objetivos idênticos de todos os entes do grupo.

Porém, o Fisco tem encontrado uma barreira significativa contrária a sua pretensão, qual seja, a interpretação restritiva da expressão “interesse comum” firmada pelo STJ, tema que será abordado em tópico apartado em momento posterior.

\subsubsection{Da infração à ordem econômica}

A Lei n. 12.529/2011, responsável por estruturar o Sistema Brasileiro de Defesa da Concorrência e dispor sobre a prevenção e repressão às infrações contra a ordem econômica, em seu art. $1^{\mathrm{o}}$ disciplina que:

Art. $1^{\circ}$ Esta Lei estrutura o Sistema Brasileiro de Defesa da Concorrência - SBDC e dispõe sobre a prevenção e a repressão às infraçóes contra a ordem econômica, orientada pelos ditames constitucionais de liberdade de iniciativa, livre concorrência,

CARVALHO, Paulo de Barros. Curso de direito tributário. 19. ed. São Paulo: Saraiva, 2007, p. 346-347. 
A responsabilidade tributária das sociedades integrantes de grupos econômicos de fato • •

função social da propriedade, defesa dos consumidores e repressão ao abuso do poder econômico. (Grifos nossos).

Parágrafo único. A coletividade é a titular dos bens jurídicos protegidos por esta Lei.

Baseado neste dispositivo, o Fisco tem defendido que a ordem tributária é uma projeção da ordem econômica, pois por meio dos tributos, principalmente os extrafiscais, o Estado atua regulando a economia, além de financiar as mais diversas atividades que beneficiarão toda a coletividade.

Para o Fisco, defender a ordem tributária é defender o patrimônio público formado pela arrecadação dos tributos. Como o Estado é financiado por toda a coletividade, a defesa da ordem tributária deve ser entendida como um interesse difuso, estando a noção de um Estado Forte e comprometido com os objetivos determinados pela Constituição Federal atrelada a uma arrecadação tributária eficiente e pautada pelo princípio da capacidade contributiva, segundo o qual "cada cidadão deve participar do custeio dos tributos, segundo a sua capacidade de pagá-los".

Neste diapasão, um grupo societário que blinda seu patrimônio, utilizando-se das sociedades controladas para evitar o pagamento do tributo estará onerando toda a sociedade e atentando contra o patrimônio público, além de estar prejudicando a livre concorrência, tendo em vista que terá maior potencial competitivo do que aquela empresa que paga todos os seus tributos corretamente. Diante disto, seria inquestionável que não só a ordem tributária restaria corrompida, como também a ordem econômica.

Utilizando-se deste cenário, o Fisco busca a aplicação do art. 33 da Lei n. 12.529/11, que prevê, como já dito anteriormente, a reponsabilidade solidária das empresas ou entidades integrantes de grupo econômico, de fato ou de direito, quando pelo menos uma delas praticar infração à ordem econômica.

Porém, a argumentação pautada somente por esta tese não vem sendo aceita pela jurisprudência, da mesma forma que não é bem recepcionada por boa parte da doutrina, o que tem feito o Fisco utiliza-la somente atrelada a outra linha argumentativa.

\subsubsection{Da sociedade de segundo grau}

A Tese da Sociedade de Segundo Grau ou também chamada Tese da Sociedade em Comum é encabeçada na doutrina pelos ensinamentos de Comparato e Salomão Filho, segundo os quais todos os grupos societários reuniriam "os três 
•• Tributação, direitos fundamentais e desenvolvimento

elementos fundamentais de toda relação societária, a saber, a contribuição individual com esforços ou recursos, a atividade para lograr fins comuns e a participação em lucros ou prejuízos" ${ }^{98}$. Diante disto, os grupos societários deveriam ser encarados como se uma sociedade fosse, onde as empresas agrupadas seriam como os empresários.

Para o Fisco, mesmo o legislador não reconhecendo a personalidade jurídica desta sociedade de segundo grau formada pelas sociedades agrupadas, há necessariamente entre elas uma unidade de direção e uma intercomunicação patrimonial, onde as empresas agrupadas atuam como meros executores das políticas definidas pela controladora. Diante disto, o grupo deveria ser tratado como se fosse uma única sociedade, podendo seu patrimônio ser atingido diretamente, sem necessidade de utilização do instituto da desconsideração da personalidade jurídica.

A fim de melhor embasar a capacidade tributária dos grupos societários, o Fisco se utiliza do art. 126, III do CTN, in verbis:

Art. 126. A capacidade tributária passiva independe: (...)

III - de estar a pessoa jurídica regularmente constituída, bastando que configure uma unidade econômica ou profissional.

O Ex-Procurador da Fazenda Nacional, então Procurador do MP junto ao Tribunal de Contas do Estado da Paraíba Bradson Tibério L. Camelo defende a aplicação conjunta da solidariedade de fato com a Tese da sociedade em comum, ao afirmar que

(...) os grupos de fato constituem, na verdade, uma sociedade em comum, devido a apresentarem os elementos fundamentais da relação societária e de empresas. Assim, há claro interesse comum de todas as pessoas jurídicas envolvidas no fato gerador, pois todas se beneficiam dos atos empresariais. (...) A solidariedade passiva resta configurada quando várias pessoas jurídicas que formam um grupo econômico de fato utilizam-se dos benefícios empresariais decorrentes da atividade empresarial. Desse modo, há solidariedade tributária entre todas as pessoas jurídicas formadoras do grupo econômico de fato, assim como ocorre quando várias pessoas naturais "empresariam" as sociedades em comum (sociedades de fato). ${ }^{99}$

Apesar da Tese da Sociedade de Segundo Grau encontrar bastante aceitação na doutrina, não é bem aceita pela jurisprudência, principalmente pela expressa

98 COMPARATO, Fábio Konder; SALOMÃO FILHO, Calixto. O poder de controle na sociedade anônima. 5. ed. Rio de Janeiro: Forense, 2008, p. 43.

99 CAMELO, Bradson Tibério Luna. Solidariedade tributária de grupo econômico de fato. Revista Dialética de Direito Tributário, n. 170, p. 21. 
A responsabilidade tributária das sociedades integrantes de grupos econômicos de fato

determinação do art. 266 da Lei n. 6.404/76 de que as sociedades agrupadas conservam sua personalidade e seu patrimônio ao se filiarem em grupos societários.

\subsubsection{Da desconsideração da personalidade jurídica}

Conforme oportunamente explicitado no início deste Capítulo, a limitação da responsabilidade dos sócios de uma sociedade está atrelada a personalização jurídica do ente coletivo. A pessoa jurídica é uma ficção criada pela lei com o intuito de permitir que os empresários se expusessem aos riscos da atividade empresarial, pois sua personalidade serve como escudo para o patrimônio de seus sócios.

Com a instituição da responsabilidade limitada dos sócios em nosso ordenamento jurídico, "foi plantada a semente para o surgimento da teoria da desconsideração da personalidade jurídica, cujo surgimento é atribuído à evolução jurisprudencial do direito Anglo Americano ${ }^{100}$ ". Isto porque, sob o véu da personalidade, os sócios se encontravam livres para cometer os mais variados tipos de abuso contra credores.

A Teoria da Desconsideração da Personalidade Jurídica pode ser conceituada como "aquela que permite ao juiz desconsiderar a autonomia jurídica da personalidade da empresa e da personalidade de seus sócios, toda vez que a sociedade tiver sido utilizada para fins ilegais ou que prejudiquem seus credores", determinando a constrição dos bens dos sócios para pagar dívidas da sociedade, dos bens da sociedade para pagar dívidas dos sócios, ou mesmo dos bens de uma empresa para pagar dívidas de outra empresa, como ocorre nos grupos econômicos ${ }^{101}$.

Dentro do conceito acima exposto é possível a identificação de desdobramentos do instituto da desconsideração, com referência à teoria maior, que permite a desconsideração direta da personalidade jurídica, à desconsideração "inversa”, que ocorre quando o sócio utiliza a sociedade como escudo de proteção de seus bens pessoais e à desconsideração indireta da personalidade jurídica, que ocorre quando, em um grupo societário repleto de empresas filiadas, a controladora ou uma das controladas se vale dessa condição para fraudar seus credores, aplicando-se a desconsideração para todas as sociedades agrupadas.

\footnotetext{
100 ANDRIGHI, Fátima Nancy. Desconsideração da personalidade jurídica. Brasília, DF, 2004. Disponível em: <http://bdjur.stj.gov.br/xmlui/handle/2011/673>. Acesso em: 12 ago. 2015. 101 Ibidem.
} 
-. Tributação, direitos fundamentais e desenvolvimento

O Fisco tem utilizado a teoria da desconsideração da personalidade jurídica inversa para os grupos societários, valendo-se da previsão contida no art. 50 do Código Civil, in verbis:

Art. 50. Em caso de abuso da personalidade jurídica, caracterizado pelo desvio de finalidade, ou pela confusão patrimonial, pode o juiz decidir, a requerimento da parte, ou do Ministério Público quando lhe couber intervir no processo, que os efeitos de certas e determinadas relaçôes de obrigações sejam estendidos aos bens particulares dos administradores ou sócios da pessoa jurídica.

O Código Civil disciplina que a desconsideração ocorrerá quando estiver configurado o abuso de personalidade, através do desvio de finalidade e da confusão patrimonial. O desvio de finalidade ocorre quando a pessoa jurídica extrapola as determinaçôes contidas de seu ato constitutivo ou se extingue irregularmente. Já a confusão patrimonial ocorre quando há, literalmente, confusão entre o patrimônio da sociedade e dos sócios, ou entre o da sociedade controladora e o da controlada.

Nos grupos societários é muito comum que ocorra a transferência de ativos e passivos, custos e lucros entre as sociedades controladas e as controladoras ${ }^{102}$, sendo nesta característica fática que o Fisco concentra suas energias, a fim de provar a ocorrência da transferência de patrimônio entre as sociedades e justificar o pedido de desconsideração da personalidade jurídica.

\subsection{A não aplicação da teoria da desconsideração aos grupos societários}

No caso dos grupos societários, alguns autores, influenciados pela brilhante doutrina de José Lamartine Corrêa de Oliveira, defendem a impossibilidade de aplicação da teoria da desconsideração da personalidade jurídica.

Segundo o indigitado autor, a confusão patrimonial é algo inerente aos grupos societários, onde as sociedades controladas e controladoras operam trocas patrimoniais internas e corriqueiras. Além disto, também seria algo recorrente na relação grupal o desvio de finalidade, resultante da perda da autonomia e independência das sociedades controladas, que muitas vezes funcionam como mero departamento da sociedade dominadora ${ }^{103}$.

102 ANDRIGHI, Fátima Nancy. Desconsideração da personalidade jurídica. Brasília, DF, 2004. Disponível em: <http://bdjur.stj.gov.br/xmlui/handle/2011/673>. Acesso em: 12 ago. 2015.

103 HOLLANDA, Pedro Ivan Vasconcelos, op. cit., p. 179 apud OLIVEIRA, José Lamartine Corrêa de. A dupla crise da pessoa jurídica. São Paulo: Saraiva, 1979, p. 599. 
A responsabilidade tributária das sociedades integrantes de grupos econômicos de fato

Diante deste entendimento, seria possível concluir que a aplicação da teoria da desconsideração da personalidade jurídica não seria condizente com a própria natureza dos grupos societários de fato, pois, levando-a à risca, os grupos nem mesmo poderiam existir, ressalvados os grupos de direito, que determinam, através do contrato, o âmbito de atuação das sociedades agrupadas e as possibilidades de trocas patrimoniais. Segundo Lamartine:

Desconsiderar a pessoa jurídica controlada, imputando seu comportamento à controladora, e fazendo-o com fundamento na mera circunstância do controle, é mais que desconsiderar: é já pôr em dúvida o próprio sistema, no que tange à asserção, contida em seu âmbito, e segundo a qual a criação do grupo de sociedades não afeta o quadro das pessoas jurídicas, já que nem extingue a personalidade das sociedades que se integram no grupo, nem faz surgir a do próprio grupo ${ }^{104}$.

Para o autor, haveria uma crise de estrutura no direito societário, pautada em um paradoxo regulatório, uma vez que, de um lado, pela teoria da desconsideração da personalidade jurídica não se admite o abuso de personalidade da sociedade, por outro, anui-se a possibilidade de controle de uma sociedade sobre a outra, atuando como se estivessem unidas por uma única personalidade jurídica, que, por sua vez, não é reconhecida pelo ordenamento jurídico ${ }^{105}$.

Diante deste cenário, Lamartine discute duas possibilidades de responsabilização que poderiam substituir a aplicação, segundo ele errônea, da teoria da desconsideração da personalidade jurídica, quais sejam, a responsabilidade subsidiária e a imputação direta. Segundo o autor, a sociedade controladora deveria ser subsidiariamente responsável pelos débitos de suas controladas, nos casos em que o controle seja efetivamente exercido pela primeira sobre a segunda, o que afastaria a crise de estrutura do direito societário. Além disto, a responsabilização deveria ser imputada diretamente à sociedade controladora, no caso da teoria da aparência ou do comportamento contraditório, pois aquele "que criou a aparência ou se comportou contraditoriamente responde por ato próprio"106.

${ }^{104}$ HOLLANDA, Pedro Ivan Vasconcelos, op. cit., p. 180 apud OLIVEIRA, José Lamartine Corrêa de. A dupla crise da pessoa jurídica. São Paulo: Saraiva, 1979, p. 594.

105 Ibidem, p. 181 apud OLIVEIRA, José Lamartine Corrêa de. A dupla crise da pessoa jurídica. São Paulo: Saraiva, 1979, p. 613-614.

106 Ibidem, p. 182 apud OLIVEIRA, José Lamartine Corrêa de. A dupla crise da pessoa jurídica. São Paulo: Saraiva, 1979, p. 611. 
•• Tributação, direitos fundamentais e desenvolvimento

\subsubsection{A jurisprudência do STJ}

A análise do tratamento dado aos grupos societários em outros ordenamentos jurídicos tem mostrado um papel fundamental da jurisprudência na construção do conceito jurídico dos grupos societários ${ }^{107}$. No Brasil, não poderia ser diferente, tendo em vista a rasa disciplina oferecida aos grupos societários pela legislação e as inúmeras discussões doutrinárias sobre o tema.

A partir deste cenário, o ponto crucial desta última parte do trabalho será a verificação da relação da jurisprudência do Superior Tribunal de Justiça com os resultados obtidos pelos estudos doutrinários e da aplicação das conclusões alcançadas pela Corte aos conflitos entre os grupos e o Fisco, principalmente no tocante a solidariedade de fato e a desconsideração da personalidade jurídica.

A Professora Dra Viviane Muller Prado ${ }^{108}$, juntamente com a pesquisadora Maria Clara Troncoso ${ }^{109}$ realizaram um importante estudo jurisprudencial acerca das decisões do STJ sobre grupos societários. As referidas pesquisadoras formaram um banco de dados com 106 acórdãos do Tribunal a fim de alcançarem as seguintes informações: 1) Expressões utilizadas nos acórdãos; 2) Matéria objeto da decisão; 3) Elementos constantes da decisão que fundamentam a existência de um grupo de sociedades; e 4) Efeitos jurídicos que decorrem da constatação da existência de um grupo de sociedades no caso concreto.

A primeira constatação das pesquisadoras foi que as expressões utilizadas pelos julgados eram tão variadas quanto as nomenclaturas utilizadas pelos diferentes diplomas legislativos que trazem alguma regulamentação sobre os grupos. A maioria dos acórdãos utilizaram as expressōes "grupo econômico", somente "grupo" ou "grupo financeiro", aparecendo poucas vezes a expressão "grupo de sociedades", utilizada pela legislação societária. Além disto, alguns julgadores utilizaram a expressão "empresas coligadas" como sinônimo de "grupo", o que está incorreto segundo a Lei n. 6.404/76 .

107 PRADO, Viviane Muller; TRONCOSO, Maria Clara. Os grupos de empresas na jurisprudência do STJ. Artigos DireitoGV, Working Papers, n. 1, nov. 2007. Disponível em: <http:// bibliotecadigital.fgv.br/ dspace/handle/10438/2771>. Acesso em: 13 ago. 2015.

108 Professora na Escola de Direito de São Paulo da Fundação Getúlio Vargas. Doutora em Direito Comercial pela Faculdade de Direito da Universidade de São Paulo.

109 Pesquisadora júnior da Escola de Direito de São Paulo da Fundação Getúlio Vargas.

110 Na lei de sociedades por ações coligação tem um sentido próprio e significa apenas sociedades nas quais a investidora tenha influência significativa. Considera-se que há influência signifi- 
A responsabilidade tributária das sociedades integrantes de grupos econômicos de fato

Outro interessante resultado obtido na pesquisa é o que faz referência às matérias objeto dos acórdãos analisados. As pesquisadoras constataram que as matérias que possuem alguma previsão legislativa específica acerca dos grupos societários aparecem consideravelmente menos do que aquelas que não possuem tal regulamentação, como pode ser visto através da tabela ${ }^{111}$ abaixo:

\begin{tabular}{|l|c|c|}
\hline \multicolumn{1}{|c|}{ Matéria } & Frequencia & $(\%)$ \\
\hline Processual & 30 & 28.38 \\
\hline Títulos de crédito & 20 & 18.98 \\
\hline Responsabilidade Civil & 12 & 11.28 \\
\hline Tributário & 9 & 8.46 \\
\hline Falencia & 7 & 6.58 \\
\hline Criminal & 6 & 5.64 \\
\hline Civil & 5 & 4.70 \\
\hline Trabalhista & 5 & 4.70 \\
\hline Consumidor & 4 & 3.76 \\
\hline Societário & 4 & 3.76 \\
\hline Fraude & 2 & 1.88 \\
\hline Administrativo & 1 & 0.94 \\
\hline Lei de imprensa & 1 & 0.94 \\
\hline TOTAL & $\mathbf{1 0 6}$ & $\mathbf{1 0 0}$ \\
\hline
\end{tabular}

As pesquisadoras também analisaram os critérios utilizados pelos julgadores para a caracterização dos grupos societários. Em 64,8\% dos acórdãos analisados os julgadores não tiveram a preocupação de apontar os elementos que os motivaram a identificar a formação grupal. Dos 35 julgados que mencionaram as razôes para decidir pela existência de grupo, 22 relacionaram ao controle ou ao poder de decisão nas companhias. Sobre estes resultados as pesquisadoras trazem uma interessante indagação:

cativa quando a investidora detém ou exerce o poder de participar nas decisões das políticas financeira ou operacional da investida, sem controlá-la ou quando a investidora for titular de $20 \%$ ou mais do capital votante da investida, sem controlá-la (art. 243 Lei n. 6.404/76).

111 PRADO, Viviane Muller; TRONCOSO, Maria Clara. Os grupos de empresas na jurisprudência do STJ, p. 19. 
•• Tributação, direitos fundamentais e desenvolvimento

Constata-se que a preocupação da dogmática jurídica, em especial do direito comparado, para identificar os elementos que caracterizam os grupos societários, seja apenas o controle seja os critérios para identificar a unidade de direção, não está presente na jurisprudência do STJ, o que nos leva a afirmar a não judicialização deste tema no nosso pais ${ }^{112}$.

Por fim, Viviane Muller Prado e Maria Clara Troncoso concluem que não existe na jurisprudência do STJ um posicionamento uniforme. Para as pesquisadoras o motivo disto é que os entendimentos firmados pelo Tribunal foram sendo construídos de forma desarticulada dos dispositivos legais e das discussões doutrinárias, tendo em vista que nos acórdãos não se observa, nem mesmo, a utilização das terminologias comumente adotadas pelo legislador e pela doutrina ${ }^{113}$.

Construído este cenário geral através da valorosa contribuição do estudo realizado pelas ilustres pesquisadoras supracitadas, passa-se a analisar especificamente a abordagem do Superior Tribunal de Justiça acerca da solidariedade de fato nos grupos societários e também da desconsideração da personalidade jurídica no ente grupal.

Conforme explicitado no tópico 3.2.1.1 do presente trabalho, o Fisco se utiliza da solidariedade de fato do art. 124, I do Código Tributário Nacional para justificar a solidariedade das sociedades integrantes de um grupo societário de fato. Tal dispositivo prevê que são solidariamente responsáveis pelo pagamento do tributo as pessoas que possuem interesse comum na situação que constitua o fato gerador da obrigação principal.

A solidariedade pelo interesse comum é um dos meios pelos quais o Fisco procura sanar a falta de regramento sobre a responsabilização das sociedades agrupadas, mácula tanto do direito societário, quanto do direito tributário. Como sua aplicação ocorre de forma direta, sem que haja a necessidade de regulamentação legislativa, a tese resolveria grande parte dos problemas causados pelos grupos societários à arrecadação do Estado.

Porém, a pretensão do Fisco encontra uma notável barreira para a sua aceitação, qual seja, a interpretação restritiva do Superior Tribunal de Justiça ao termo "interesse comum", configurador da solidariedade de fato. A fim de explicar essa questão, o presente trabalho irá se ater aos julgados que significaram a mudança de entendimento do Tribunal quanto ao tema da solidariedade nos grupos societários.

112 Ibidem, p. 21.

113 Ibidem, p. 29. 
No ano de 2007, em decisão no Recurso Especial n. 859.616, o relator Ministro Luiz Fux decidiu pela impossibilidade de se aplicar a solidariedade entre as empresas somente por elas pertencerem ao mesmo grupo econômico, sob o argumento de que a expressão “interesse comum” do art. 124, I do CTN não estaria querendo expressar o interesse econômico, mas sim o interesse jurídico na situação que constitua o fato gerador, como se depreende da decisão, senão vejamos:

PROCESSUAL CIVIL. TRIBUTÁRIO. RECURSO ESPECIAL. ISS. EXECUÇÃO FISCAL. TÍTULOS DA DÍVIDA PÚBLICA (LETRAS FINANCEIRAS DO TESOURO). AUSÊNCIA DE LIQUIDEZ E CERTEZA. RECUSA. POSSIBILIDADE. MENOR ONEROSIDADE. ART. 620 DO CPC. SÚMULA 7/STJ. LEGITIMIDADE PASSIVA. EMPRESAS DO MESMO GRUPO ECONÔMICO. SOLIDARIEDADE. INEXISTÊNCIA.

(...) 4. Na relação jurídico-tributária, quando composta de duas ou mais pessoas caracterizadas como contribuinte, cada uma delas estará obrigada pelo pagamento integral da dívida, perfazendo-se o instituto da solidariedade passiva. Ad exemplum, no caso de duas ou mais pessoas serem proprietárias de um mesmo imóvel urbano, haveria uma pluralidade de contribuintes solidários quanto ao adimplemento do IPTU, uma vez que a situação de fato - a copropriedade - é-lhes comum.

(...)

6. Deveras, o instituto da solidariedade vem previsto no art. 124 do CTN, verbis: "Art. 124. São solidariamente obrigadas: I - as pessoas que tenham interesse comum na situação que constitua o fato gerador da obrigação principal; II - as pessoas expressamente designadas por lei."

7. Conquanto a expressão "interesse comum" - encarte um conceito indeterminado, é mister proceder-se a uma interpretação sistemática das normas tributárias, de modo a alcançar a ratio essendi do referido dispositivo legal. Nesse diapasão, tem-se que o interesse comum na situação que constitua o fato gerador da obrigação principal implica que as pessoas solidariamente obrigadas sejam sujeitos da relação jurídica que deu azo à ocorrência do fato imponível. Isto porque feriria a lógica jurídico- tributária a integração, no polo passivo da relação jurídica, de alguém que não tenha tido qualquer participação na ocorrência do fato gerador da obrigação.

8. Segundo doutrina abalizada, in verbis: “... o interesse comum dos participantes no acontecimento factual não representa um dado satisfatório para a definiçáo do vínculo da solidariedade. Em nenhuma dessas circunstâncias cogitou o legislador desse elo que aproxima os participantes do fato, o que ratifica a precariedade do método preconizado pelo inc. I do art. 124 do Código. Vale sim, para situações em que não haja bilateralidade no seio do fato tributado, como, por exemplo, na incidência do IPTU, em que duas ou mais pessoas são proprietárias do mesmo imóvel. Tratando-se, porém, de ocorrências em que o fato se consubstancie pela presença de pessoas em posiçóes contrapostas, com objetivos antagônicos, a solidariedade vai 
•• Tributação, direitos fundamentais e desenvolvimento

instalar-se entre sujeitos que estiveram no mesmo polo da relação, se e somente se for esse o lado escolhido pela lei para receber o impacto jurídico da exação. É o que se dá no imposto de transmissão de imóveis, quando dois ou mais são os compradores; no ICMS, sempre que dois ou mais forem os comerciantes vendedores; no ISS, toda vez que dois ou mais sujeitos prestarem um único serviço ao mesmo tomador" (Paulo de Barros Carvalho, in Curso de Direito Tributário, Saraiva, 8. ed., 1996, p. 220).

9. Destarte, a situação que evidencia a solidariedade, quanto ao ISS, é a existência de duas ou mais pessoas na condição de prestadoras de apenas um único serviço para o mesmo tomador, integrando, desse modo, o polo passivo da relação. Forçoso concluir, portanto, que o interesse qualificado pela lei não há de ser o interesse econômico no resultado ou no proveito da situação que constitui o fato gerador da obrigação principal, mas o interesse jurídico, vinculado à atuação comum ou conjunta da situação que constitui o fato imponível.

10. In casu, verifica-se que o Banco Alfa S/A não integra o polo passivo da execução, tão somente pela presunção de solidariedade decorrente do fato de pertencer ao mesmo grupo econômico da empresa Alfa Arrendamento Mercantil S/A. Há que se considerar, necessariamente, que são pessoas jurídicas distintas e que referido banco não ostenta a condição de contribuinte, uma vez que a prestação de serviço decorrente de operações de leasing deu-se entre o tomador e a empresa arrendadora. 11. Recurso especial parcialmente provido, para excluir do polo passivo da execução o Banco Alfa S/A, mantida a penhora imposta pelo Tribunal a quo.

(STJ, Relator: Ministro LUIZ FUX, Data de Julgamento: 18/09/2007, T1 - PRIMEIRA TURMA).

Porém, a Segunda Turma do Tribunal, nos autos do AgRg no REsp n. 900.484/RS de relatoria do Ministro Humberto Martins, no mesmo ano em que a decisão anteriormente citada havia sido proferida, utilizou-se do entendimento que já vinha sendo aplicado pelo STJ em julgados anteriores, no sentido de que a empresa controladora do grupo econômico teria legitimidade passiva ad causam para constar da relação jurídica, conforme ementa abaixo:

TRIBUTÁRIO - EXECUÇÃO FISCAL - NOMEAÇÃO DE BENS À PENHORA - ORDEM LEGAL - RECUSA DO BEM - INEXISTÊNCIA DE ILEGALIDADE - ART. 11 DA LEF.

(...)

3. Sobre a questão concernente à exclusão do banco-recorrente do polo passivo da relação jurídica, o STJ, em casos análogos, entende que diante da constatação da existência de grupo econômico ou conglomerado financeiro a empresa líder tem legitimidade passiva ad causam para constar da relação jurídica. (Grifos nossos).

(...) Agravo regimental improvido

(STJ, Relator: Ministro HUMBERTO MARTINS, Data de Julgamento: 21/06/2007, T2 - SEGUNDA TURMA). 
A responsabilidade tributária das sociedades integrantes de grupos econômicos de fato

Configurado o dissídio pretoriano, o Município de São Leopoldo suscitou a divergência, através dos Embargos de Divergência em Recurso Especial, cujo relator era o Ministro Mauro Campbell Marques, pugnando pela prevalência do entendimento exarado pelo Ministro Humberto Martins e o consequente afastamento da decisão proferida pelo Ministro Luiz Fux. Porém, prevaleceu o entendimento restritivo, conforme se depreende do acórdão, senão vejamos:

PROCESSUAL CIVIL. EMBARGOS DE DIVERGÊNCIA NO RECURSO ESPECIAL. TRIBUTÁRIO. ISS. EXECUÇÃO FISCAL. PESSOAS JURÍDICAS QUE PERTENCEM AO MESMO GRUPO ECONÔMICO. CIRCUNSTÂNCIA QUE, POR SI SÓ, NÃO ENSEJA SOLIDARIEDADE PASSIVA.

1. $O$ entendimento prevalente no âmbito das Turmas que integram a Primeira Seção desta Corte é no sentido de que o fato de haver pessoas jurídicas que pertençam ao mesmo grupo econômico, por si só, não enseja a responsabilidade solidária, na forma prevista no art. 124 do CTN. Ressalte-se que a solidariedade não se presume (art. 265 do CC/2002), sobretudo em sede de direito tributário. Precedentes: EREsp 834044/RS, Primeira Seção, Rel. Min. Mauro Campbell Marques, julgado em 8.9.2010; REsp 1.079.203/SC, 2a Turma, Rel. Min. Eliana Calmon, DJe de 2.4.2009; REsp 1.001.450/RS, 2a Turma, Rel. Min. Castro Meira, DJe de 27.3.2008; AgRg no Ag 1.055.860/RS, 1a Turma, Rel. Min. Denise Arruda, DJe de 26.3.2009. 2. Embargos de divergência não providos.

(STJ, Relator: Ministro MAURO CAMPBELL MARQUES, Data de Julgamento: 09/02/2011, S1 - PRIMEIRA SEÇÃO)

Hoje, a jurisprudência do Superior Tribunal de Justiça é pacífica em determinar que a expressão “interesse comum” quer significar o interesse jurídico, ou seja, as empresas agrupadas para serem solidariamente responsáveis, devem ser sujeitos da relação jurídica que deu azo à ocorrência do fato gerador, concorrendo conjuntamente para que o fato imponível tenha sido realizado, sendo irrelevante a participação no resultado dos eventuais lucros auferidos pelas outras empresas.

No que tange a desconsideração da personalidade jurídica nos grupos societários, a questão é menos controvertida do que aquela tratada anteriormente. $\mathrm{O}$ estudo dos julgados do STJ sobre o tema mostra que os Ministros tratam a desconsideração com bastante cautela, por ser uma decisão bastante gravoso para as sociedades. Porém, o entendimento que vem prevalecendo é o de concordância à aplicação do instituto nos grupos societários, como se verá a seguir.

A análise da jurisprudência referente à aplicação da teoria da desconsideração da personalidade jurídica nos grupos societários, foi pautada nos acórdãos proferidos pelo STJ nos últimos cinco anos, utilizando-se como critério de busca, no 
•• Tributação, direitos fundamentais e desenvolvimento

próprio endereço eletrônico do Tribunal, as expressões "grupo econômico", "grupo de sociedades" e "desconsideração". Através destes critérios de busca, foi possível identificar 24 acórdãos emanados pelo STJ nos últimos cinco anos, de onde é possível se retirar algumas conclusões esclarecedoras acerca do tema.

A primeira delas é que muitos Ministros se utilizam de precedente de relatoria da Ministra Nancy Andrighi no Recurso Ordinário em MS n. 12.872/SP, para justificarem seus posicionamentos. Neste precedente, julgado em 2002, a referida Ministra, pioneiramente, defende a desconsideração da personalidade jurídica de sociedade pertencente a um grupo econômico sob um mesmo controle e estrutura meramente formal, como se observa do julgado abaixo:

PROCESSO CIVIL. RECURSO ORDINÁRIO EM MANDADO DE SEGURANÇA. FALÊNCIA. GRUPO DE SOCIEDADES. ESTRUTURA MERAMENTE FORMAL. ADMINISTRAÇÃO SOB UNIDADE GERENCIAL, LABORAL E PATRIMONIAL. DESCONSIDERAÇÃO DA PERSONALIDADE JURÍDICA DA FALIDA. EXTENSÃO DO DECRETO FALENCIAL A OUTRA SOCIEDADE DO GRUPO. POSSIBILIDADE. TERCEIROS ALCANÇADOS PELOS EFEITOS DA FALÊNCIA. LEGITIMIDADE RECURSAL.

Pertencendo a falida a grupo de sociedades sob o mesmo controle e com estrutura meramente formal, o que ocorre quando as diversas pessoas jurídicas do grupo exercem suas atividades sob unidade gerencial, laboral e patrimonial, é legitima a desconsideração da personalidade jurídica da falida para que os efeitos do decreto falencial alcancem as demais sociedades do grupo. - Impedir a desconsideração da personalidade jurídica nesta hipótese implicaria prestigiar a fraude à lei ou contra credores. (...) (grifos nossos)

(STJ - RMS: 12872 SP 2001/0010079-1, Relator: Ministra NANCY ANDRIGHI, Data de Julgamento: 24/06/2002, T3 - TERCEIRA TURMA,

Data de Publicação: DJ 16.12.2002 p. 306).

Segundo o entendimento da Ministra, não defender a desconsideração da personalidade jurídica no caso das sociedades agrupadas exercerem suas atividades sob unidade gerencial, laboral e patrimonial (o que geralmente ocorre nos grupos societários de fato) seria privilegiar a fraude à lei e aos credores. Este entendimento da Ministra Nancy Andrighi é o precedente que vem sendo adotado pelo STJ para os casos análogos, desde de 2002, como pode ser visto dos julgados abaixo transcritos:

DIREITO CIVIL E PROCESSUAL CIVIL. DESCONSIDERAÇĀO DA PERSONALIDADE JURÍDICA. FRAUDE CONTRA CREDORES. CONFUSÃO PATRIMONIAL. RECONHECIMENTO. INCIDÊNCIA DA SÚMULA 7/STJ. CERCEAMENTO DE DEFESA. INEXISTÊNCIA.

1. No sistema de persuasão racional adotado pelo Código de Processo Civil nos arts. 130 e 131, em regra, não cabe compelir o magistrado a autorizar a produção desta ou 
A responsabilidade tributária das sociedades integrantes de grupos econômicos de fato

daquela prova, se por outros meios estiver convencido da verdade dos fatos, tendo em vista que o juiz é o destinatário final da prova, a quem cabe a análise da conveniência e necessidade da sua produção.

2. O acórdão recorrido tem fundamentação robusta acerca da existência de confusão patrimonial entre empresas do mesmo grupo econômico, com a finalidade de fraudar credores. Assim, é cabível a desconsideração da personalidade jurídica, nos termos do art. 50 do Código Civil, bem como o reconhecimento da fraude à execução, com amparo na Súmula n. 375/STJ: "O reconhecimento da fraude à execução depende do registro da penhora do bem alienado ou da prova de má-fé do terceiro adquirente”. Incidência da Súmula 7/STJ. (Grifos nossos).

3. Agravo regimental não provido.

(AgRg no AREsp 231558/PR AGRAVO REGIMENTAL NO AGRAVO EM RECURSO ESPECIAL 2012/0197405-8 - RELATOR: Ministro LUIS

FELIPE SALOMÃO - T4 - QUARTA TURMA. Data do Julgamento 18/12/2014 - Data da Publicação/Fonte DJe 02/02/2015)

RECURSO ORDINÁRIO. MANDADO DE SEGURANÇA. AÇÃO DE FALÊNCIA. DESCONSIDERAÇÃO DA PERSONALIDADE JURÍDICA (CC/2002, ART. 50). SOCIEDADE EMPRESÁRIA IMPETRANTE PERTENCENTE AO MESMO GRUPO ECONÔMICO DA FALIDA. DESNECESSIDADE DE AÇÃO AUTÔNOMA. IMPRESCINDIBILIDADE DO CONTRADITÓRIO (CF, ART. 5, LIV E LV). RECURSO ORDINÁRIO PARCIALMENTE PROVIDO.

1. É possível atingir, com a desconsideração da personalidade jurídica, empresa pertencente ao mesmo grupo econômico da sociedade empresária falida, quando a estrutura deste é meramente formal, sendo desnecessário o ajuizamento de ação autônoma para a verificação de fraude ou confusão patrimonial. Precedentes. (Grifos nossos).

(...)

4. Recurso ordinário parcialmente provido.

(RMS 29697/RS RECURSO ORDINÁRIO EM MANDADO DE SEGURANÇA 2009/0112254-0 Relator(a) Ministro RAUL ARAÚJO (1143)

Órgão Julgador QUARTA TURMA Data do Julgamento 23/04/2013 Data da Publicação/Fonte DJe 01/08/2013)

RECURSO ESPECIAL. EMPRESARIAL. PROCESSO CIVIL. DESCONSIDERAÇÃO DA PERSONALIDADE JURÍDICA.

CUMPRIMENTO DE SENTENÇA. RECONHECIMENTO DE GRUPO ECONÔMICO. REVISÃO DOS FATOS AUTORIZADORES. SÚMULA N $7 /$ STJ. NULIDADE POR FALTA DE CITAÇÃO AFASTADA. EFETIVO PREJUÍZO PARA A DEFESA NÃO VERIFICADO. OFENSA À COISA JULGADA INEXISTENTE. AUSÊNCIA DE NEGATIVA DE PRESTAÇÃO JURISDICIONAL. SÚMULA N. 98/STJ. 
-. Tributação, direitos fundamentais e desenvolvimento

1. Reconhecido o grupo econômico e verificada confusão patrimonial, é possível desconsiderar a personalidade jurídica de uma empresa para responder por dívidas de outra, inclusive em cumprimento de sentença, sem ofensa à coisa julgada. Rever a conclusão no caso dos autos é inviável por incidir a Súmula n. 7/STJ.

2. A falta de citação da empresa cuja personalidade foi desconsiderada, por si só, não induz nulidade, capaz de ser reconhecida apenas nos casos de efetivo prejuízo ao exercício da defesa, inexistente na hipótese.

3. Recurso conhecido em parte e, nessa parte, provido. (Grifos nossos).

(REsp 1253383/MT RECURSO ESPECIAL 2011/0075097-0 Relator(a) Ministro RICARDO VILLAS BÔAS CUEVA (1147) T3 - TERCEIRA

TURMA Data do Julgamento 12/06/2012 Data da Publicação/Fonte DJe 05/10/2012)

Para aqueles que defendem a não aplicação da teoria da desconsideração da personalidade jurídica aos grupos, como já explicitado anteriormente, o precedente da Ministra Nancy Andrighi não seria correto para embasar a aplicação da teoria, isto porque ele estrutura a argumentação na existência da unidade gerencial, laboral e patrimonial. Segundo Anna Beatriz Alves Margoni:

A direção unitária é elemento caracterizador dos grupos de sociedades, embora tal conceito não seja previsto na LSA. Existindo uma direção unitária na realidade fática dos grupos, é esperado que exista unidade gerencial, laboral e patrimonial entre as sociedades que o integram. Esta unidade, contudo, não é, de pronto, ensejadora de confusão patrimonial, abuso de direito ou fraude a credores (embora isso possa ocorrer na prática e, neste caso, o abuso deve sim ser reprimido). Ela é inerente à figura dos grupos ${ }^{114}$.

Para esta parte da doutrina a desconsideração da personalidade jurídica vem sendo utilizada pelos Tribunais como um meio de proteção aos credores, suprindo uma justiça que não pode ser feita através da aplicação da lei. Com isto, a teoria acaba sendo utilizada, no caso dos grupos societários, sem que se evidencie o abuso, a fraude ou outro dos requisitos do art. 50 do CC, mas sim um elemento inerente aos grupos societários de fato ${ }^{115}$.

\section{CONCLUSÃO}

Adentrar no tema da responsabilização das sociedades que integram grupos societários é andar por um caminho árduo e cheio de incertezas. Atingir conclusóes acertadas e objetivas sobre ele, então, mostra-se um desafio. Porém, diante de toda

114 MARGONI, Anna Beatriz Alves. A desconsideração da personalidade jurídica nos grupos de sociedades. Dissertação apresentada à Faculdade de Direito da Universidade de São Paulo. São Paulo, 2011, p. 150.

115 Ibidem, p. 150. 
A responsabilidade tributária das sociedades integrantes de grupos econômicos de fato • • esta complexidade, é preciso observar que as soluções mais servíveis ao bom direito devem ser aquelas que estejam vinculadas à realidade da sociedade.

A primeira conclusão sobre o trabalho aqui apresentado seria sobre a situação da legislação brasileira frente aos grupos societários. $\mathrm{O}$ direito brasileiro não tem se mostrado apto a enfrentar uma realidade fática tão complexa como a construída pelos grupos societários. A Lei n. 6.404/76 nasce pautada na doutrina tradicional da sociedade comercial isoladamente considerada, balizada pela autonomia, independência jurídica e responsabilidade limitada, ao passo que atua na vanguarda do disciplinamento sobre os grupos societários no direito pátrio. Além disto, a referida lei direciona praticamente todos os seus esforços para um modelo de grupo que é adotado de forma irrisória no Brasil.

$\mathrm{Na}$ mesma esteira, a doutrina nacional atua de forma muito branda na discussão do tema e, quando o enfrenta, bebe fortemente das doutrinas internacionais, que arduamente discutem sobre os grupos societários em suas respectivas realidades.

Por conseguinte, o judiciário vem tendo que enfrentar cada vez mais causas que versam sobre os direitos de credores frente as sociedades integrantes de grupos societários de fato (devido a vaguidade legislativa), mostrando-se afastado de qualquer critério na discussão dos grupos societários. Tal é a desorientação, que Viviane Muller Prado e Maria Clara Troncoso chegaram à conclusão pela não judicialização do tema ao analisarem os julgados do STJ (Item 3.2.1.5).

Os grupos societários de fato, representantes da real expressão do fenômeno grupal na realidade societária brasileira devem, ainda hoje, travestir-se sob o manto da sociedade comercial individualizada, o que propicia graves consequências jurídicas, como, por exemplo, a frustração dos direitos dos credores, que no caso do crédito tributário é o Estado.

Fato interessante é que o surgimento da ideia de grupo societário contratual e da unidade de tratamento das empresas de um mesmo grupo se deu no direito tributário alemão. "Para evitar a tributação dos dividendos distribuídos nos vários níveis das sociedades pertencentes a um mesmo grupo, criaram-se mecanismos contratuais para tratar de maneira unificada a empresa formada por várias sociedades $^{116}$. Porém, como já anteriormente explicitado o direito brasileiro importou parcialmente o modelo alemão, sem se preocupar com as consequências jurídicas

116 PRADO, Viviane Muller. Grupos societários: análise do modelo da Lei 6.404/1976. Revista Direito GV, São Paulo, v. 1, n. 2, jun./dez. 2005, p. 9. 
•• Tributação, direitos fundamentais e desenvolvimento

posteriores que um regramento fracionado e próprio de uma realidade jurídica e social diversa poderia ocasionar.

A Lei n. 6.404/76 garante a manutenção da personalidade jurídica das sociedades agrupadas, ao mesmo tempo que proíbe a atuação da controladora de forma a fazer com que as controladas percam a sua autonomia, somente sendo tal situação aceitável quando há convenção grupal (grupos de direito). Aos grupos de fato aplicam-se as regras previstas para as sociedades isoladas. Porém, na prática os grupos societários de fato constituem expressão máxima do poder de controle grupal, existindo ali controle, direção unitária e influência dominante. Hollanda, de forma muito coerente, pontua tal questão da seguinte forma:

Os próprios limites da personalidade jurídica não devem ser intransponíveis, pois as sociedades comerciais não são um fim em si mesmas, mas representam um campo de imputação dos mais variados interesses, como o dos sócios (minoritários ou não), dos fornecedores, dos investidores, dos consumidores, dos trabalhadores, dos credores, do meio ambiente, do Estado etc. A personalização jurídica não pode representar a identificação do ente coletivo com os interesses dos seus integrantes, ainda mais nas sociedades componentes dos grupos societários, que tratam, geralmente, de atividades empresariais de grande escala, com alcance a um inimaginável número de pessoas ${ }^{117}$.

O Fisco enfrenta diariamente grandes potências econômicas articuladas em grupos societários de fato, que blindam poderosas empresas controladoras através de minguadas empresas controladas, que são utilizadas para assumir créditos que não poderão ser satisfeitos. Esta blindagem tem se mostrado extremamente eficiente, principalmente pelos posicionamentos restritivos adotados pela jurisprudência dos Tribunais Superiores.

Apontar soluções para a questão seria algo muitíssimo pretensioso da minha parte, principalmente porque ela pede uma conclusão demasiadamente complexa, que demandaria uma profundidade maior no tema. Porém, após o estudo e a elaboração deste trabalho, uma conclusão indiscutível a que se pode chegar é sobre a necessidade urgente de restruturação da legislação, seja societária ou tributária, que discipline de forma pormenorizada o fenômeno grupal no Brasil.

A realidade dos grupos societários é assustadoramente mutável, o que dificulta muito o disciplinamento da matéria, mas é preciso que o direito determine limites e consequências para o exercício do fenômeno grupal, sobretudo informando-o através do princípio da justiça distributiva.

HOLLANDA, Pedro Ivan Vasconcelos. op. cit., p. 207. 
A responsabilidade tributária das sociedades integrantes de grupos econômicos de fato

\section{REFERÊNCIAS}

ANDRIGHI, Fátima Nancy. Desconsideração da personalidade jurídica. Brasília, DF, 2004. Disponível em: <http://bdjur.stj.gov.br/xmlui/handle/2011/673>. Acesso em: 12 ago. 2015. ANTUNES, José A. Engrácia. Os grupos de sociedade estrutura e organização jurídica da empresa plurissocietária. 2. ed. Coimbra: Almedina, 2002.

ANTUNES, José Augusto Quelhas Lima Engrácia. Os grupos de sociedades: estrutura e organização jurídica da empresa plurisocietária. 2. ed., rev. e atual. Coimbra: Almedina, 2002.

CAMELO, Bradson Tibério Luna. Solidariedade tributária de grupo econômico de fato. Revista Dialética de Direito Tributário, n. 170.

CARVAlHO, Paulo de Barros. Curso de direito tributário. 19. ed. São Paulo: Saraiva, 2007.

COMPARATO, Fábio Konder; SALOMÃO FILHO, Calixto. O poder de controle na sociedade anônima. 5. ed. Rio de Janeiro: Forense, 2008.

DARZÉ, Andréa Medrado. Responsabilidade tributária solidária. Breves considerações sobre os artigos 124 e 125 do Código Tributário Nacional. In: FREIRE, Elias Sampaio; DIAS, Karem Jureidini; QUEIROZ, Mary Elbe (Coord.). Grandes questôes em discussão no CARF. São Paulo: FocoFiscal, 2014.

HOLLANDA, Pedro Ivan Vasconcelos. Os grupos societários como superação do modelo tradicional da sociedade comercial autônoma, independente e dotada de responsabilidade limitada. Universidade Federal do Paraná. Curitiba, 2008.

LIMA, Marcelo Cordeiro de; MIRANDA, Bernadete. Grupo de empresas. Revista Virtual Direito Brasil, v. 3, n. 1, 2009.

LOBO, Jorge. Direito dos grupos de sociedades. Revista de Direito Mercantil, Industrial, Econômico e Financeiro, São Paulo: RT, n. 107.

MARGONI, Anna Beatriz Alves. A desconsideração da personalidade jurídica nos grupos de sociedades. Dissertação (Mestrado) - Faculdade de Direito da Universidade de São Paulo, São Paulo, 2011.

PEREIRA, Guilherme Döring Cunha. Alienação do poder de controle acionário. São Paulo: Saraiva, 1995.

PINTO, Rodrigo Martins de Oliveira Silva. Os grupos de sociedades no direito antitruste: um estudo das concentrações empresariais. Curitiba, 2010.

PRADO, Viviane Muller. Conflito de interesses nos grupos societários. São Paulo: Quartier Latin, 2006.

PRADO, Viviane Muller. Grupos societários: análise do modelo da Lei 6.404/1976. Revista Direito GV, São Paulo, v. 1, n. 2, jun./dez. 2005. 
•• Tributação, direitos fundamentais e desenvolvimento

PRADO, Viviane Muller; TRONCOSO, Maria Clara. Os grupos de empresas na jurisprudência do STJ. Artigos DireitoGV, Working Papers, n. 1, nov. 2007. Disponível em: <ttp://bibliotecadigital.fgv.br/ dspace/handle/10438/2771>. Acesso em: 13 ago. 2015.

RAMOS, André Luiz Santa Cruz. Direito empresarial esquematizado. 4. ed. rev., atual. e ampl. Rio de Janeiro: Forense; São Paulo.

SANTO, João Espírito. Sociedades por quotas e anónimas - vinculação: objecto social e representação plural. Coimbra: Almedina, 2000.

TOMAZETTE, Marlon. Curso de direito empresarial: teoria geral e direito societário. 3. ed. São Paulo: Atlas, 2011. v. 1.

Valor Grandes Grupos, n. 3, dez. 2004. Disponível em: <http://www.revistavalor.com. br/home. aspx? pub $=19$ \&edicao $=9>$. 